BNL-114426-2017-JA

\title{
Synthesis of cryptomelane type alpha-MnO2 (KxMn8016) cathode materials with tunable $K+$ content: the role of tunnel cation concentration on electrochemistry
}

\author{
A. S. Poyraz, Y. Zhu
}

Submitted to Journal of Materials Chemistry A

August 2017

Condensed Matter Physics and Materials Science Department

Brookhaven National Laboratory

\author{
U.S. Department of Energy \\ USDOE Office of Science (SC), \\ Basic Energy Sciences (BES) (SC-22)
}




\section{DISCLAIMER}

This report was prepared as an account of work sponsored by an agency of the United States Government. Neither the United States Government nor any agency thereof, nor any of their employees, nor any of their contractors, subcontractors, or their employees, makes any warranty, express or implied, or assumes any legal liability or responsibility for the accuracy, completeness, or any third party's use or the results of such use of any information, apparatus, product, or process disclosed, or represents that its use would not infringe privately owned rights. Reference herein to any specific commercial product, process, or service by trade name, trademark, manufacturer, or otherwise, does not necessarily constitute or imply its endorsement, recommendation, or favoring by the United States Government or any agency thereof or its contractors or subcontractors. The views and opinions of authors expressed herein do not necessarily state or reflect those of the United States Government or any agency thereof. 


\section{Journal Name}

\section{ARTICLE}

\section{Synthesis of Cryptomelane Type $\alpha-\mathrm{MnO}_{2}\left(\mathrm{~K}_{\mathrm{x}} \mathrm{Mn}_{8} \mathrm{O}_{16}\right)$ Cathode Materials with Tunable $\mathrm{K}^{+}$Content: The Role of Tunnel Cation Concentration on Electrochemistry}

Received 00th January 20xx Accepted 00th January 20xx

DOI: $10.1039 / \times 0 \times x 00000 x$

www.rsc.org/
Altug S. Poyraz, ${ }^{a}$ Jianping Huang, ${ }^{b}$ Christopher J. Pelliccione, ${ }^{a}$ Xiao Tong, ${ }^{\text {a Shaobo Cheng, }}{ }^{\text {ac }}$ Lijun

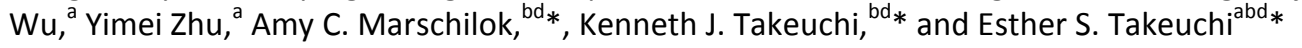

\section{Introduction}

One dimensional (1D) tunnel structured cryptomelane type manganese dioxides, $\mathrm{Mn}_{8} \mathrm{O}_{16}\left(\alpha-\mathrm{MnO}_{2}\right)$ are interesting cathode materials as they can reversibly host various cations including $\mathrm{Li}^{+} . \alpha$ $-\mathrm{MnO}_{2}$ type materials are often synthesized with the addition of a metal cation central to the tunnel structure. Potassium containing cryptomelane type manganese dioxide $\left(\alpha-\mathrm{MnO}_{2}, \mathrm{~K}_{\mathrm{x}} \mathrm{Mn}_{8} \mathrm{O}_{16}, \mathrm{~K}\right.$-OMS2 ) is an important and well-studied nanomaterial in the fields of catalysis, adsorption-separation, and ion-exchange. ${ }^{1-7} \alpha-\mathrm{MnO}_{2}$ consists of one dimensional $2 \times 2(0.46 \times 0.46 \mathrm{~nm})$ tunnels formed by corner and edge sharing manganese octahedral $\left[\mathrm{MnO}_{6}\right]$ units adopting a $14 / \mathrm{m}$ tetragonal crystal structure (See Fig. $\mathrm{S} 1)^{2,5,6,8} \cdot \ln \alpha-$ $\mathrm{MnO}_{2}$ materials, manganese is mixed valent $(3+$ and $4+)$ where charge neutrality is maintained by cations residing in the tunnels. The most common form is $\mathrm{K}^{+}$containing $\alpha-\mathrm{MnO}_{2}\left(\mathrm{~K}_{\mathrm{x}} \mathrm{Mn}_{8} \mathrm{O}_{16}\right)$, however, the $2 \times 2$ tunnels of $\alpha-\mathrm{MnO}_{2}$ can reversibly host various

\footnotetext{
a. Energy Sciences Directorate, Brookhaven National Laboratory, Upton, NY 11973, USA.

b. Department of Chemistry, Stony Brook University, Stony Brook, NY 11794, USA. c. Department of Materials Science and Engineering, Tsinghua University, Beijing, 100084, China.

${ }^{d .}$ Department of Materials Science and Engineering, Stony Brook University, Stony Brook, NY 11794, USA.

*corresponding authors: (ACM) amy.marschilok@stonybrook.edu, (KJT) kenneth.takeuchi.1@stonybrook.edu, (EST) esther.takeuchi@stonybrook.edu + Electronic Supplementary Information (ESI) available.
}

other cations such as $\mathrm{Ag}^{+}, \mathrm{H}_{3} \mathrm{O}^{+}, \mathrm{Na}^{+}, \mathrm{Li}^{+} \mathrm{Zn}^{2+}$, and $\mathrm{Mg}^{2+} \cdot{ }^{8-14} \alpha-\mathrm{MnO}_{2}$ materials possess a rich chemistry and easily interchange stable oxidation states. Tunnel structured manganese oxides exhibit interesting electrical and ionic conductivities. ${ }^{15}$ Therefore, along with low-toxicity and high abundance of manganese, $\alpha-\mathrm{MnO}_{2}$ emerges as an interesting rechargeable battery cathode. The electrochemical charge storage by insertion/deinsertion of monoand divalent cations $\left(\mathrm{Li}^{+}, \mathrm{Na}^{+}, \mathrm{Mg}^{2+}\right.$, and $\left.\mathrm{Zn}^{2+}\right)$ into the tunnels of $\alpha$ $\mathrm{MnO}_{2}$ has previously been reported. ${ }^{10,11,13,14,16-18}$

As a cathode material in rechargeable Li batteries, $\alpha-\mathrm{MnO}_{2}$ has a theoretical specific capacity of $300 \mathrm{mAh} / \mathrm{g}$ and energy density exceeding $500 \mathrm{Wh} / \mathrm{kg}$. Although several reports provide the reversible lithium ion storage into $\alpha-\mathrm{MnO}_{2}$ materials, the reported lithium-based electrochemistry varies significantly, with significant differences in the reported initial discharge capacity, discharge profile, and capacity retention with cycling for $\mathrm{K}^{+}$containing $\alpha$ $\mathrm{MnO}_{2}\left(\mathrm{~K}_{\mathrm{x}} \mathrm{Mn}_{8} \mathrm{O}_{16}\right)$ materials synthesized by different methods. An initial discharge capacity of $360 \mathrm{mAh} / \mathrm{g}(100 \mathrm{~mA} / \mathrm{g}$ rate) with a Sshaped discharge curve and voltage plateau at $\sim 2.3 \mathrm{~V}$ for $\mathrm{K}_{1.0} \mathrm{Mn}_{8} \mathrm{O}_{16}$ prepared by a hydrothermal reaction at $120^{\circ} \mathrm{C}$ has been reported. ${ }^{16}$ A voltage profile with no distinct voltage plateau (single slopped line) and an initial capacity of $200 \mathrm{mAh} / \mathrm{g}$ (C/2 rate) was reported for material synthesized via a high temperature hydrothermal method $\left(200^{\circ} \mathrm{C}\right) .{ }^{19} \quad \mathrm{~K}_{0.72} \mathrm{Mn}_{8} \mathrm{O}_{16}$ materials prepared by a low temperature $\left(80^{\circ} \mathrm{C}\right)$ hydrothermal method demonstrated a stepwise potential variation consisting of two S-shaped curves with voltage plateaus at $2.6 \mathrm{~V}$ and $2.3 \mathrm{~V}$ with an initial discharge capacity 
of $250 \mathrm{mAh} / \mathrm{g}$ (10 mA/g rate). ${ }^{20}$ Redox sol-gel and acid digestion are other two common synthetic techniques employed for the synthesis of $\mathrm{K}_{\mathrm{x}} \mathrm{Mn}_{8} \mathrm{O}_{16}$ which showed $\mathrm{S}$-shaped discharge curves with voltage plateaus of $3.0 \mathrm{~V}$ and $2.45 \mathrm{~V}^{21,22}$ Despite their relatively high plateau voltages, these materials synthesized by solgel $\left(\mathrm{K}_{1.2} \mathrm{Mn}_{8} \mathrm{O}_{16}\right)$ and acid digestion $\left(\mathrm{K}_{1.3} \mathrm{Mn}_{8} \mathrm{O}_{16}\right)$ methods showed modest initial discharge capacities, 160 and $188 \mathrm{mAh} / \mathrm{g}$, when tested at $0.1 \mathrm{~mA} / \mathrm{cm}^{2}$ and $50 \mathrm{~mA} / \mathrm{g}$, respectively. In addition, the presence of $\mathrm{K}^{+}$ions in $\alpha-\mathrm{MnO}_{2}$ can impact the pseudo-capacitive performance of $\mathrm{K}_{\mathrm{x}} \mathrm{Mn}_{8} \mathrm{O}_{16}$ material by increasing the amount of $\mathrm{Mn}^{3+}$. The pseudo-capacitance resulting from the $\mathrm{Mn}^{4+} / \mathrm{Mn}^{3+}$ redox couple contributed to the total capacitance of the $\mathrm{K}_{x} \mathrm{Mn}_{8} \mathrm{O}_{16}$ electrode, which was $\sim 140 \%$ of the capacitance of the $\mathrm{K}^{+}$-free $\mathrm{MnO}_{2}$ electrode. ${ }^{23}$

Notably, the previously reported $\mathrm{K}_{\mathrm{x}} \mathrm{Mn}_{8} \mathrm{O}_{16}$ materials had differences in several physicochemical properties (i.e surface area, crystallite size, and chemical composition ( $\mathrm{K}^{+}$content), 2, 6, 24-27 resulting from differences in their preparation methods, where several factors may contribute to the observed differences in their electrochemistry. Similarly, $\alpha-\mathrm{MnO}_{2}$ materials can be prepared without a tunnel metal cation by several methods, including approaches in which the material is synthesized without a tunnel metal cation present, or approaches that remove the central tunnel metal cation after synthesis. Examples of the former case include a precipitation method using ozone as oxidant, and thermal treatment of $\left(\mathrm{NH}_{4}\right)_{x} \mathrm{Mn}_{8} \mathrm{O}_{16}{ }^{12,13,28-30}$ An example of the latter is use of nitric acid treatment to lower the potassium content of $\mathrm{K}_{2} \mathrm{Mn}_{8} \mathrm{O}_{16} \cdot{ }^{31}$ For the central tunnel metal cation free and low metal cation content $\alpha-\mathrm{MnO}_{2}$ materials, the method used for removal of the tunnel metal cation can significantly impact physicochemical properties in addition to the chemical composition.

In this report, we developed a hydrothermal synthetic method to systematically control the $\mathrm{K}^{+}$content of $\mathrm{K}_{\mathrm{x}} \mathrm{Mn}_{8} \mathrm{O}_{16}$ materials using a consistent synthesis approach. Our objective of keeping physicochemical properties (surface area, crystallite size, surface defects) and morphology similar across the series was validated through detailed characterization of the as-prepared materials, including $x$-ray diffraction, thermal analysis, inductively coupled plasma-optical emission spectroscopy, $x$-ray photoelectron spectroscopy, and transmission electron microscopy. The electrochemistry of the $\mathrm{K}_{\mathrm{x}} \mathrm{Mn}_{8} \mathrm{O}_{16}$ materials with varying $\mathrm{K} / \mathrm{Mn}$ ratios (0.000 to 0.094$)$ was evaluated through galvanostatic discharge and cycling, rate capability, and Li ion diffusion coefficient determination. The structural changes of the materials occurring as result of lithiation were investigated using $X$-ray absorption spectroscopy (XAS). This study provides an unambiguous investigation regarding the role of the monovalent structural central tunnel metal cation $\left(\mathrm{K}^{+}\right)$on the electrochemistry of a tunnel structured material $\left(\alpha-\mathrm{MnO}_{2}\right)$.

\section{Experimental}

\subsection{Materials Synthesis}

Potassium containing cryptomelane type manganese dioxides $\left(\mathrm{K}_{\mathrm{x}} \mathrm{Mn}_{8} \mathrm{O}_{16}\right)$ with different $\mathrm{K}^{+}$amounts were synthesized using a modified version of a hydrothermal redox reaction using
$\mathrm{MnSO}_{4} \cdot \mathrm{H}_{2} \mathrm{O}$ and $\left(\mathrm{NH}_{4}\right)_{2} \mathrm{~S}_{2} \mathrm{O}_{8}$, where the $\mathrm{K}^{+}$content was adjusted by using different amounts of $\left(\mathrm{NH}_{4}\right)_{2} \mathrm{SO}_{4}$ and $\mathrm{K}_{2} \mathrm{SO}_{4} \cdot{ }^{30}$ In a typical synthesis procedure $0.51 \mathrm{~g} \mathrm{(} 3 \mathrm{mmol})$ of $\mathrm{MnSO}_{4} \cdot \mathrm{H}_{2} \mathrm{O}$ and $6 \mathrm{mmol}$ of (ammonium $\left(\left(\mathrm{NH}_{4}\right)_{2} \mathrm{SO}_{4}\right)$ and/or potassium $\left(\mathrm{K}_{2} \mathrm{SO}_{4}\right)$ ) were dissolved in $10 \mathrm{~mL} \mathrm{DDI} \mathrm{with} 1.37 \mathrm{~g}(6 \mathrm{mmol})$ of $\left(\mathrm{NH}_{4}\right)_{2} \mathrm{~S}_{2} \mathrm{O}_{8}$ water at $\mathrm{RT}$ in a PTFE vessel. The vessel was transferred to a stainless steel autoclave and heated at $120^{\circ} \mathrm{C}$ for $48 \mathrm{~h}$. The resulting solid products were annealed at $400^{\circ} \mathrm{C}$ for $3 \mathrm{~h}$ to remove $\mathrm{NH}_{4}{ }^{+12}$ The powder samples are designated as $\mathrm{K}_{\mathrm{x}} \mathrm{Mn}_{8} \mathrm{O}_{16}$, where $\mathrm{X}$ is the amount of $\mathrm{K}^{+}$ (determined by ICP-OES) in the prepared material per structural formula of $\mathrm{K}_{\mathrm{x}} \mathrm{Mn}_{8} \mathrm{O}_{16} \cdot \mathrm{yH}_{2} \mathrm{O}$.

\subsection{Characterization}

\subsubsection{Materials Characterization}

Powder X-ray diffraction (PXRD) patterns of $\mathrm{K}_{\mathrm{x}} \mathrm{Mn}_{8} \mathrm{O}_{16}$ samples were collected using a Rigaku Smart Lab X-ray diffractometer. $\mathrm{Cu}$ Ka radiation ( $\lambda=1.5406 \AA$ ) was used with Bragg-Brentano focusing geometry. Synchrotron $X$-ray diffraction was conducted at the NSLSII XPD 28-ID-2 beamline at Brookhaven National Laboratory, and the beam wavelength was calibrated to $0.1899 \AA$. The Fit $2 D^{32}$ and GSAS ${ } \mathrm{II}^{33}$ were used to convert data and carry out Rietveld refinement, respectively. Nitrogen $\left(\mathrm{N}_{2}\right)$ sorption (adsorption-desorption) measurements were performed using a Quantachrome Nova 4200e instrument and surface area of the samples were calculated using multipoint BET (Brunauer, Emmett, and Teller) method. Thermogravimetric analysis (TGA) was performed using a TA instruments SDT $Q 600$ instrument under $10 \mathrm{cc} / \mathrm{min}$ air flow between $25-900^{\circ} \mathrm{C}$. $\mathrm{K}^{+}$content of $\mathrm{K}_{\mathrm{x}} \mathrm{Mn}_{8} \mathrm{O}_{16}$ materials was determined quantitatively using a Thermo Scientific iCAP 6000 series inductively coupled plasma optical emission spectroscopy (ICP-OES) instrument. Raman spectra were collected using a Horiba Scientific Xplora Raman Spectrometer with $1 \%$ laser power $(\lambda=532 \mathrm{~nm})$ and 50x optical lens. Scanning electron microscopy (SEM) images were collected using JEOL JSM-6010PLUS instrument with the accelerating voltage of $20 \mathrm{kV}$. A JEOL ARM-200F aberration corrected transmission electron microscope at Brookhaven National Laboratory (BNL) was used for the acquirement of both low magnification and high resolution transmission electron microscopy (TEM) images. The microscope is equipped with cold field emission gun and two aberration correctors. The point resolution for TEM mode is better than $0.7 \AA \AA$. X-ray photoelectron spectroscopy (XPS) experiments were carried out in a UHV chamber equipped with SPECS Phoibos $100 \mathrm{MCD}$ analyzer and a non-monochromatized Mg$\mathrm{K} \alpha \mathrm{X}$-ray source ( $\mathrm{hv}=1253.6 \mathrm{eV}$ ) operating with an accelerating voltage of $10 \mathrm{kV}$ and $30 \mathrm{~mA}$ current. The chamber typically has a base pressure of $2 \times 10^{-10}$ Torr. The powder samples were pressed onto a conductive copper tape and mounted on the sample holder. Charging effects were corrected by adjusting the binding energy of the $\mathrm{C}(1 \mathrm{~s})$ peak at $284.8 \mathrm{eV}$.

X-ray absorption spectroscopy (XAS) measurements were collected at Sector 12-BM at the Advanced Photon Source at Argonne National Laboratory at the Mn K-edge (6.539 keV) with a Si (111) double crystal monochromator. The combination of flat and toroidal mirrors facilitated a focused spot size of ca. $1.5 \mathrm{~mm} \times 0.5$ $\mathrm{mm}$. Spectra were collected in transmission mode with samples positioned perpendicular to the incident beam and situated 
between ionization chambers filled with $100 \% \mathrm{~N}_{2}$. Data were collected to $\mathrm{k}=18 \AA^{-1}(1.231 \mathrm{keV})$ above the nominal Mn K-edge edge position, with two scans measured per sample that were later merged to reduce the noise at large $\mathrm{k}$ values. A Mn foil standard was utilized for initial beam energy calibration, and was also measured simultaneously with each sample to ensure proper energy alignment of multiple scans. $\mathrm{K}_{0.00} \mathrm{Mn}_{8} \mathrm{O}_{16}, \mathrm{~K}_{0.32} \mathrm{Mn}_{8} \mathrm{O}_{16}$, and $\mathrm{K}_{0.75} \mathrm{Mn}_{8} \mathrm{O}_{16}$ samples were electrochemically discharged to $0,0.1$, 0.3 and 0.5 Faradaic electron equivalents discharge in a standard coin-type cell, extracted, removed from Al foil current collector and sealed between Kapton tape in an inert atmosphere glovebox. Each sample was stored in an inert environment until XAS measurement to limit any possible oxidation. Samples were also cycled 50 times, and extracted in both the $50^{\text {th }}$ discharged (reduced) and charged (oxidized) states for XAS measurements.

XAS spectra were aligned, merged, deglitched and normalized using Athena. ${ }^{34,}{ }^{35}$ The built-in AUTOBK algorithm was utilized to minimize background contributions below $R_{b k g}=1.0 \AA$. . All extended $X$-ray absorption fine structure (EXAFS) spectra were fit using a model derived from the I $4 / \mathrm{m} \mathrm{Ag}_{1.8} \mathrm{Mn}_{8} \mathrm{O}_{16}$ crystal structure ${ }^{36}$, with theoretical models created via FEFF6. ${ }^{37,38}$ Each spectrum was fit using a k-range of $2.0-15.5 \AA^{-1}$ using a Hanning window in $k, k^{2}$ and $\mathrm{k}^{3} \mathrm{k}$-weightings simultaneously. The fit was conducted over an $\mathrm{R}$ range of $1.0-3.5 \AA$ to fully encompass the neighboring $\mathrm{Mn}-\mathrm{Mn}$ coordination shells. Each distinct $\mathrm{Mn}-\mathrm{Mn}$ coordination (along the caxis, edge sharing octahedra and corner sharing octahedra within the $a-b$ plane) was allowed to vary independently from the others with respect to interatomic distances and Debye-Waller factors that account for static and thermal disorder. Intrinsic losses accompanying the electron scattering process were accounted for by obtaining $\mathrm{S}_{0}{ }^{2}$, the amplitude reduction factor, from modeling a $\mathrm{Mn}$ metal standard and applying to all experimental fits to achieve a more accurate measure of the number of neighboring atoms. Using this procedure, a $\mathrm{S}_{0}{ }^{2}$ of 0.85 was applied to all fits. All presented fits resulted in $\mathrm{R}$-factors less than $1.5 \%$ over the fitted range. Full fitting results are presented in the Supplemental Information.

\subsubsection{Electrochemical Characterization}

Composite cathode coatings were prepared on an aluminum foil by mixing conductive carbon (15 wt. \%), active material (70 wt. \%), and polyvinylidene fluoride (PVDF) binder (15 wt. \%) using the doctor blade method. Stainless steel experimental type coin cells with lithium metal anodes were fabricated in an argon atmosphere glove box. Composite coatings, separator, lithium metal, and electrolyte consisting of $1 \mathrm{M} \mathrm{LiPF}_{6}$ in ethylene carbonate-dimethylcarbonate (30:70 vol. \%) were employed in the cells. Cyclic voltammetry data were recorded with a scan rate of $0.1 \mathrm{mV} / \mathrm{s}$ and voltage limits of 1.5 to $4.0 \mathrm{~V}$. Galvanostatic intermittent titration technique (GITT) type testing was conducted with an intermittent discharge current of $100 \mathrm{~mA} / \mathrm{g}$ for $2 \mathrm{~min}$ followed by open circuit rest for $5 \mathrm{~h}$. Cell discharge/charge and rate capability tests were performed using a Maccor testing system. The cells were cycled with a $50 \mathrm{~mA} / \mathrm{g}$ rate between 2.0- $3.5 \mathrm{~V}$ during the discharge/charge test. A rate capability test was performed with the rates of 10, 20, 50, 100, 200, 400,50 , and $10 \mathrm{~mA} / \mathrm{g}$ in the voltage range of 2.0 to $3.5 \mathrm{~V}$.

\section{Results}

\subsection{Materials Synthesis and Characterization}

$\mathrm{K}_{\mathrm{x}} \mathrm{Mn}_{8} \mathrm{O}_{16}$ materials with varying amounts of $\mathrm{K}^{+}$were prepared using a hydrothermal procedure and resulting $\mathrm{K} / \mathrm{Mn}$ ratios are presented in Table 1. The $\mathrm{K} / \mathrm{Mn}$ ratio increases from 0.00 to 0.094 with increasing $\mathrm{K}_{2} \mathrm{SO}_{4}$ reagent amounts. Fig. 1a shows the PXRD patterns of $\mathrm{K}_{\mathrm{x}} \mathrm{Mn}_{8} \mathrm{O}_{16}$ materials. Regardless of the $\mathrm{K}^{+}$content, all diffraction lines of $\mathrm{K}_{\mathrm{x}} \mathrm{Mn}_{8} \mathrm{O}_{16}$ materials are indexed to the synthetic cryptomelane phase $\left(\mathrm{K}_{\mathrm{x}} \mathrm{Mn}_{8} \mathrm{O}_{16}\right.$, JCPDS 029-1020). Scherrer crystallite size of (211) diffraction lines at $2 \theta=37.6^{\circ}$ and BET surface areas are reported in Table 1. All $\mathrm{K}_{\mathrm{x}} \mathrm{Mn}_{8} \mathrm{O}_{16}$ samples have similar crystallite sizes (17-19 nm) and similar surface areas (76-66 $\mathrm{m}^{2} / \mathrm{g}$, Fig. S2). Phase purity was checked by Raman spectroscopy (Fig. 1 b) as common impurity phases such as $\mathrm{MnOOH}, \mathrm{Mn}_{2} \mathrm{O}_{3}$, and $\mathrm{Mn}_{3} \mathrm{O}_{4}$ can be detected at very low concentrations by Raman spectroscopy. ${ }^{39,40}$ The Raman spectra were almost identical where all peaks $\left(183,385,581\right.$, and $\left.641 \mathrm{~cm}^{-1}\right)$ could be indexed to the pure cryptomelane phase of manganese dioxide with no impurity phases detected. Two strong bands at 578 and $634 \mathrm{~cm}^{-1}$ are attributed to $\mathrm{Mn}-\mathrm{O}$ symmetric stretching vibrations of manganese octahedra ${ }^{39}$. The peak at $180 \mathrm{~cm}^{-1}$ is attributed to the translational motion of the octahedral $\mathrm{MnO}_{6}$ units while the band at $385 \mathrm{~cm}^{-1}$ is due to the $\mathrm{Mn}$ $O$ bending mode. ${ }^{40}$ The Raman band at $\sim 630 \mathrm{~cm}^{-1}$ is attributed to the symmetric $\mathrm{Mn}-\mathrm{O}$ stretching vibration of $\mathrm{MnO}_{6}$ octahedra, where it has been noted that distortion of $\mathrm{MnO}_{6}$ due to the presence of $\mathrm{Mn}^{3+}$ can broaden the Raman band. ${ }^{41}$ The $\mathrm{K}_{0.32} \mathrm{Mn}_{8} \mathrm{O}_{16}$ material showed two shoulder peaks near the peak at $634 \mathrm{~cm}^{-1}$, implying changes in the $\mathrm{Mn}-\mathrm{O}$ distances of the $\mathrm{MnO}_{6}$ octahedra. Thus, the Raman data are consistent with our XRD refinement results below.

Thermogravimetric analysis (TGA) was performed under air to determine relative thermal stabilities and amounts of tunnel water (Fig. 1C). At temperatures below $250^{\circ} \mathrm{C}$, dehydration of physisorbed surface water occurs. ${ }^{24,40,42,43}$ At temperatures higher than $500^{\circ} \mathrm{C}$, the material undergoes decomposition to form $\mathrm{Mn}_{2} \mathrm{O}_{3}$, and then $\mathrm{Mn}_{3} \mathrm{O}_{4}{ }^{28,44,45}$ The amount of surface adsorbed (physisorbed) water in these samples was in the range of 3.8 to 4.8 w.t. \%. The
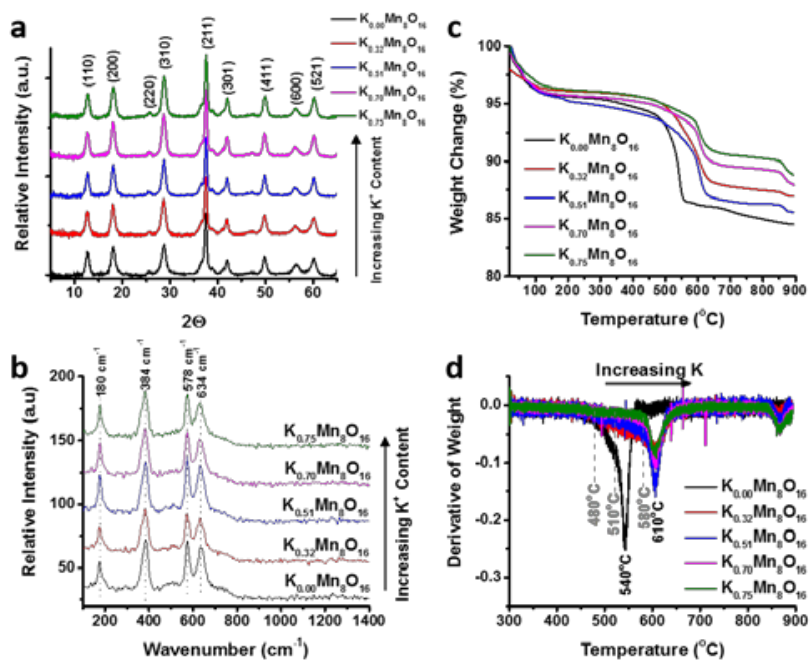
Fig. 1 (a) Powder X-ray diffraction (PXRD), (b) Raman Spectra, and (c) Thermogravimetric Analysis (TGA) profiles and (d) Derivative thermogravimetric analysis DTGA plot of $\mathrm{K}_{0.00} \mathrm{Mn}_{8} \mathrm{O}_{16}, \mathrm{~K}_{0.32} \mathrm{Mn}_{8} \mathrm{O}_{16}$, $\mathrm{K}_{0.51} \mathrm{Mn}_{8} \mathrm{O}_{16}, \mathrm{~K}_{0.70} \mathrm{Mn}_{8} \mathrm{O}_{16}$, and $\mathrm{K}_{0.75} \mathrm{Mn}_{8} \mathrm{O}_{16}$. 
Table 1. Summary of TGA, PXRD, ICP-OES and $\mathrm{N}_{2}$ Sorption results

\begin{tabular}{|c|c|c|c|c|}
\hline Sample ID & $\mathrm{K} / \mathrm{Mn}^{\mathrm{a}}$ & Structural Formula ${ }^{b}$ & Crystallite size $(\mathrm{nm})^{\mathrm{c}}$ & $\begin{array}{c}\text { Surface Area }^{d} \\
\left(\mathrm{~m}^{2} / \mathrm{g}\right)\end{array}$ \\
\hline $\mathrm{K}_{0.00} \mathrm{Mn}_{8} \mathrm{O}_{16}$ & 0.000 & $\mathrm{Mn}_{8} \mathrm{O}_{16} \cdot 0.81 \mathrm{H}_{2} \mathrm{O}$ & 18 & 76 \\
\hline $\mathrm{K}_{0.32} \mathrm{Mn}_{8} \mathrm{O}_{16}$ & 0.040 & $\mathrm{~K}_{0.32} \mathrm{Mn}_{8} \mathrm{O}_{16} \cdot 0.54 \mathrm{H}_{2} \mathrm{O}$ & 17 & 68 \\
\hline $\mathrm{K}_{0.51} \mathrm{Mn}_{8} \mathrm{O}_{16}$ & 0.064 & $\mathrm{~K}_{0.51} \mathrm{Mn}_{8} \mathrm{O}_{16} \cdot 0.75 \mathrm{H}_{2} \mathrm{O}$ & 19 & 66 \\
\hline $\mathrm{K}_{0.70} \mathrm{Mn}_{8} \mathrm{O}_{16}$ & 0.087 & $\mathrm{~K}_{0.70} \mathrm{Mn}_{8} \mathrm{O}_{16} \cdot 0.53 \mathrm{H}_{2} \mathrm{O}$ & 18 & 69 \\
\hline $\mathrm{K}_{0.75} \mathrm{Mn}_{8} \mathrm{O}_{16}$ & 0.094 & $\mathrm{~K}_{0.75} \mathrm{Mn}_{8} \mathrm{O}_{16} \cdot 0.55 \mathrm{H}_{2} \mathrm{O}$ & 18 & 73 \\
\hline
\end{tabular}

${ }^{\mathrm{a}} \mathrm{The} \mathrm{K} / \mathrm{Mn}$ ratios were determined by ICP-OES, ${ }^{\mathrm{b}}$ The structural formulas were derived from combined results of TGA (weight loss between $250^{\circ} \mathrm{C}-500^{\circ} \mathrm{C}$ to determine $\mathrm{H}_{2} \mathrm{O}$ content), ICP-OES (to determine $\mathrm{K} / \mathrm{Mn}$ ratio). ${ }^{\mathrm{C} S}$ Scherrer crystallite size from (211) diffraction line of PXRD data. ${ }^{\mathrm{d}}$ Surface area determined by Brunauer Emmett Teller (BET) method.

amount of chemisorbed (tunnel) water of the $\mathrm{K}_{\mathrm{x}} \mathrm{Mn}_{8} \mathrm{O}_{16}$ samples was determined from the weight loss between $200-500^{\circ} \mathrm{C}^{24,40,42,43}$ while tunnel water content of $\mathrm{K}_{0.00} \mathrm{Mn}_{8} \mathrm{O}_{16}$ was determined from the weight loss in the temperature range of $200-480^{\circ} \mathrm{C}$ due to its lower thermal stability. $\mathrm{K}_{0.00} \mathrm{Mn}_{8} \mathrm{O}_{16}$ showed the highest amount of tunnel water content of $2.0 \mathrm{wt} . \%$ corresponding to 0.81 units of water per structural formula (Table 1). For $\mathrm{K}^{+}$containing $\mathrm{K}_{\mathrm{x}} \mathrm{Mn}_{8} \mathrm{O}_{16}(\mathrm{x}>0)$ materials, the amounts of tunnel water were lower than 0.75 units per structural formula unit (Table 1). Higher tunnel water content was previously reported for central metal cation containing $\mathrm{Mn}_{8} \mathrm{O}_{16}$ materials where the amount of tunnel water can be as high as 2.88 units per structural formula. ${ }^{13,28,45}$ In absence of tunnel cations, more vacant tunnel sites are available for water and $\mathrm{H}_{3} \mathrm{O}^{+}$to stabilize the structure and balance the charge. ${ }^{12}$ At temperatures higher than $500^{\circ} \mathrm{C}$, the structure decomposes due to loss of lattice oxygen $\left(\mathrm{K}_{\mathrm{x}} \mathrm{Mn}_{8} \mathrm{O}_{16} \rightarrow \mathrm{Mn}_{2} \mathrm{O}_{3} \rightarrow \mathrm{Mn}_{3} \mathrm{O}_{4}\right){ }^{28,44-46}$ In order to determine relative thermal stabilities of $\alpha-\mathrm{MnO}_{2}$ materials with various $\mathrm{K}^{+}$ content, derivative thermogravimetric analysis (DTGA) are also reported (Fig. 1d). It is accepted that $\mathrm{K}^{+}$ions play an important role in stabilizing the tunnel structure of $\mathrm{K}_{\mathrm{x}} \mathrm{Mn}_{8} \mathrm{O}_{16}$ materials. ${ }^{2,} 6,12,30,46$ Thus, $\mathrm{K}_{0.00} \mathrm{Mn}_{8} \mathrm{O}_{16}$ has the lowest decomposition temperature of $540^{\circ} \mathrm{C}$ and where $\mathrm{O}_{2}$ evolution starts at $480^{\circ} \mathrm{C}$. In the presence of potassium, the thermal decomposition temperature is higher. The $\mathrm{K}_{\mathrm{x}} \mathrm{Mn}_{8} \mathrm{O}_{16}$ samples with low $\mathrm{K}^{+}$content $\left(\mathrm{K}_{0.32} \mathrm{Mn}_{8} \mathrm{O}_{16}\right.$ and $\left.\mathrm{K}_{0.51} \mathrm{Mn}_{8} \mathrm{O}_{16}\right)$ have a lower decomposition temperature $\left(510^{\circ} \mathrm{C}\right)$ compared to the samples with high $\mathrm{K}^{+}$content $\left(\mathrm{K}_{0.70} \mathrm{Mn}_{8} \mathrm{O}_{16}\right.$ and $\left.\mathrm{K}_{0.75} \mathrm{Mn}_{8} \mathrm{O}_{16}\right)\left(580^{\circ} \mathrm{C}\right)$.

\subsubsection{Synchrotron X-ray diffraction}

Tunnel dimensions (lattice parameters) of cryptomelane type manganese dioxides $\left(\mathrm{Mn}_{8} \mathrm{O}_{16}\right)$ are known to be sensitive to both cation occupancy (type and amount) and level of hydration of the tunnels. ${ }^{13,29,44,46-48}$ For example, group I metal cations such as $\mathrm{K}^{+}$ and $\mathrm{Na}^{+}$increase the tunnel dimensions, whereas $\mathrm{Ag}^{+}$decreases the tunnel dimensions. ${ }^{46,47}$ Also, lattice parameters $a$ and $b$ increase with increasing water content of the tunnels. ${ }^{13,29,44,48}$ Table S1 summarizes some previously reported lattice parameters for several central metal cation free $\mathrm{Mn}_{8} \mathrm{O}_{16}$ materials.

In order to determine the evolution of lattice parameters with increasing potassium content, Rietveld refinement of $\mathrm{K}_{0.00} \mathrm{Mn}_{8} \mathrm{O}_{16}$, $\mathrm{K}_{0.32} \mathrm{Mn}_{8} \mathrm{O}_{16}$ and $\mathrm{K}_{0.75} \mathrm{Mn}_{8} \mathrm{O}_{16}$ samples was done for synchrotron $\mathrm{x}$ ray diffraction (XRD) data (Fig. 2). To our knowledge, this is the first report showing the systematic variations of lattice parameters of $\mathrm{K}_{\mathrm{x}} \mathrm{Mn}_{8} \mathrm{O}_{16}$ with $\mathrm{K}^{+}$content where all materials were prepared using the same methodology. $\mathrm{K}^{+}$content of the $\mathrm{K}_{\mathrm{x}} \mathrm{Mn}_{8} \mathrm{O}_{16}$ materials used in the analyses were $0.00,0.32$, and 0.75 units per structural formula as determined by ICP-OES (see Table 1). Synchrotron XRD results indicate only one phase of manganese dioxide $\left(\alpha-\mathrm{MnO}_{2}\right.$, space group $14 / \mathrm{m}$ ). Resulting lattice parameters and unit cell volumes are summarized in Table 2 . In the absence of $\mathrm{K}^{+}$ $\left(\mathrm{K}_{0.00} \mathrm{Mn}_{8} \mathrm{O}_{16}\right)$, lattice parameters $\mathrm{a}$ and $\mathrm{b}$ are smaller than those of the $\mathrm{K}^{+}$containing $\alpha-\mathrm{MnO}_{2}$ samples $\left(\mathrm{K}_{0.32} \mathrm{Mn}_{8} \mathrm{O}_{16}\right.$ and $\left.\mathrm{K}_{0.75} \mathrm{Mn}_{8} \mathrm{O}_{16}\right)$.
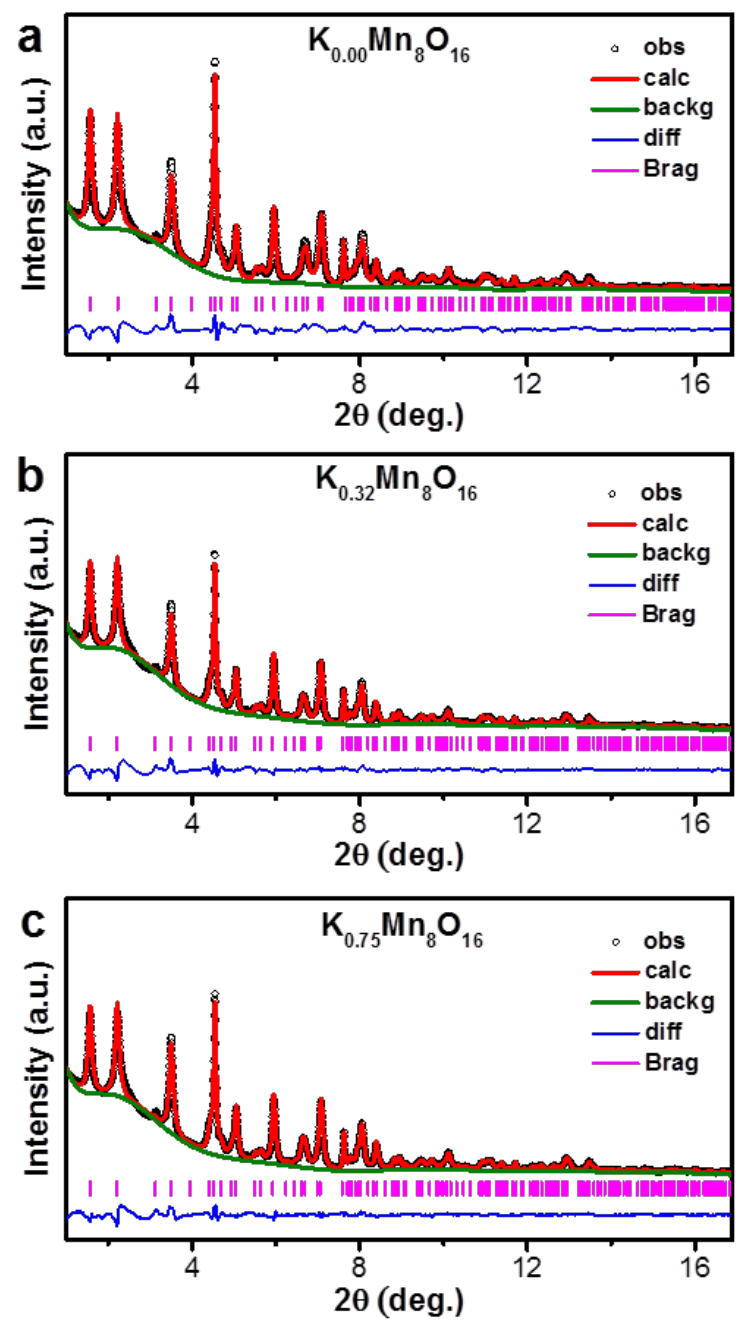

Fig. 2 Synchrotron $\mathrm{X}$-ray diffraction data and Rietveld refinement of (a) $\mathrm{K}_{0.00} \mathrm{Mn}_{8} \mathrm{O}_{16}$, (b) $\mathrm{K}_{0.32} \mathrm{Mn}_{8} \mathrm{O}_{16}$, and (c) $\mathrm{K}_{0.75} \mathrm{Mn}_{8} \mathrm{O}_{16}$. 
Table 2 Lattice Parameters from Rietveld Refinement of $\mathrm{K}_{\mathrm{x}} \mathrm{Mn}_{8} \mathrm{O}_{16}$ samples ( $14 / \mathrm{m}$ space group)

\begin{tabular}{|c|c|c|c|c|}
\hline \multicolumn{2}{|c|}{ Sample ID } & $\mathrm{K}_{0.00} \mathrm{Mn}_{8} \mathrm{O}_{16}$ & $\mathrm{~K}_{0.32} \mathrm{Mn}_{8} \mathrm{O}_{16}$ & $\mathrm{~K}_{0.75} \mathrm{Mn}_{8} \mathrm{O}_{16}$ \\
\hline \multicolumn{2}{|c|}{ Chemical Composition } & $\mathrm{Mn}_{8} \mathrm{O}_{16} \cdot 0.81 \mathrm{H}_{2} \mathrm{O}$ & $\mathrm{K}_{0.32} \mathrm{Mn}_{8} \mathrm{O}_{16} \cdot 0.54 \mathrm{H}_{2} \mathrm{O}$ & $\mathrm{K}_{0.75} \mathrm{Mn}_{8} \mathrm{O}_{16} \cdot 0.55 \mathrm{H}_{2} \mathrm{O}$ \\
\hline \multirow{3}{*}{$\begin{array}{l}\text { Lattice Constants } \\
\text { (Å) }\end{array}$} & a & $9.801(2)$ & $9.826(1)$ & $9.822(1)$ \\
\hline & b & $9.801(2)$ & $9.826(1)$ & $9.822(1)$ \\
\hline & c & $2.8601(6)$ & $2.8590(2)$ & $2.8558(1)$ \\
\hline \multicolumn{2}{|c|}{ Volume $\left(\AA^{3}\right)$} & $274.79(5)$ & $276.05(4)$ & $275.51(3)$ \\
\hline \multicolumn{2}{|c|}{$\operatorname{Rwp}(\%)^{a}$} & 4.91 & 3.59 & 3.15 \\
\hline \multicolumn{2}{|c|}{ GofF } & 1.96 & 1.30 & 1.15 \\
\hline
\end{tabular}

${ }^{\text {a }}$ Rwp is the weighted coefficient of determination for the fitting. The weights are based on assumed errors (0.01\%) in the data set. Goff is the goodness of fit. Goff $=R_{w p} / R_{\text {exp }}$, where $R_{\text {exp }}$ is the best possible fit that can be achieved if the assumed errors are correct.

The lattice parameters $a$ and $b$ are $9.801 \AA$ for $\mathrm{K}_{0.00} \mathrm{Mn}_{8} \mathrm{O}_{16}$ (Table 2), consistent with previous literature reports (Table S2). ${ }^{13,40,44,48}$ The $\mathrm{K}_{\mathrm{x}} \mathrm{Mn}_{8} \mathrm{O}_{16}$ material with the highest $\mathrm{K}^{+}$content $\left(\mathrm{K}_{0.75} \mathrm{Mn}_{8} \mathrm{O}_{16}\right)$ has lattice parameters of $9.822 \AA$ for $a$ and $b$ and $2.8558 \AA$ for $c$, in good agreement with previously reported results $(a=9.8241 \AA$ and $\mathrm{c}=2.8523 \AA$ ̊). ${ }^{40} \mathrm{Mn}-\mathrm{O}$ bond lengths and Wyckoff atomic positions are summarized in Table S2. The average $\mathrm{Mn}-\mathrm{O}$ bond distance of $\mathrm{K}_{0.00} \mathrm{Mn}_{8} \mathrm{O}_{16}(1.966 \AA)$ is larger than the $\mathrm{Mn}-\mathrm{O}$ bond distances of $\mathrm{K}^{+}$ containing $\mathrm{K}_{0.32} \mathrm{Mn}_{8} \mathrm{O}_{16}$ and $\mathrm{K}_{0.75} \mathrm{Mn}_{8} \mathrm{O}_{16}$ samples (1.947 $\mathrm{A}$ and 1.922 $\AA$, respectively). The $\mathrm{K}_{0.00} \mathrm{Mn}_{8} \mathrm{O}_{16}$ material shows longer average $\mathrm{Mn}-\mathrm{O}$ bond distances and larger variation in its $\mathrm{Mn}-\mathrm{O}$ bond distances (2.127-1.675 $\mathrm{A}$ ) relative to $\mathrm{K}_{0.32} \mathrm{Mn}_{8} \mathrm{O}_{16}(2.089-1.761 \AA$ ) and $\mathrm{K}_{0.75} \mathrm{Mn}_{8} \mathrm{O}_{16}(2.008-1.83 \AA \AA)$, see Table S1.

\subsubsection{X-ray Photoelectron Spectroscopy}

Surface chemical composition, average manganese oxidation state (AOS), and surface defect structure of $\mathrm{K}_{\mathrm{x}} \mathrm{Mn}_{8} \mathrm{O}_{16}$ materials with different potassium content were investigated with $\mathrm{X}$-ray photoelectron spectroscopy. Survey spectra of $\mathrm{K}_{\mathrm{x}} \mathrm{Mn}_{8} \mathrm{O}_{16}$ samples show the characteristic core level photoelectron peaks of $\mathrm{Mn} 2 \mathrm{p}$, $\mathrm{Mn3s}, \mathrm{Mn3p}, \mathrm{K} 2 \mathrm{~s}, \mathrm{~K} 2 \mathrm{p}, \mathrm{C} 1 \mathrm{~s}$ and $\mathrm{O} 1 \mathrm{~s}$ and Auger signals of $\mathrm{Mn}$ and $\mathrm{O}$ with no detected chemical impurities (Fig. S3). K2p, Mn3s, Mn2p, and 01 s spectral regions are shown in Fig. 3 and peak positions are reported in Table 3. An increase at the $\mathrm{K} 2 \mathrm{p}$ peak intensities can be realized with increasing $\mathrm{K}^{+}$content in the $\mathrm{K}_{\mathrm{x}} \mathrm{Mn}_{8} \mathrm{O}_{16}$ samples consistent with the results of ICP-OES (Fig. 3a). Regardless of the $\mathrm{K}^{+}$ content, line shapes and binding energies (BEs) of Mn2p signals are very similar. $\mathrm{Mn} 2 \mathrm{p}_{1 / 2}$ and $\mathrm{Mn} 2 \mathrm{p}_{3 / 2}$ peaks of $\mathrm{K}_{\mathrm{x}} \mathrm{Mn}_{8} \mathrm{O}_{16}$ samples are in the ranges of 654.12-654.05 and 642.8-642.9 eV, respectively, in agreement with the values previously reported for cryptomelane type manganese dioxides. ${ }^{43,}$ 49-54 Average oxidation state (AOS) of manganese is typically lower than $4+$ in $\mathrm{K}_{\mathrm{x}} \mathrm{Mn}_{8} \mathrm{O}_{16}$ materials due the mixed valence nature of manganese. Since the $\mathrm{Mn} 2 \mathrm{p}$ region is not sensitive enough to determine small changes at $A O S$ in $\mathrm{K}_{\mathrm{x}} \mathrm{Mn}_{8} \mathrm{O}_{16}$ materials, ${ }^{43,50,53,54}$ the $\mathrm{Mn} 3 \mathrm{~s}$ region was recorded to determine average oxidation state (AOS) of manganese (Fig. 3c). The Mn3s region consists of two peaks ( $\mathrm{Mn3s}$ and satellite peak) and the peak splitting $\left(\Delta \mathrm{E}_{\mathrm{Mn3s}}\right)$ is linearly correlated with the AOS of manganese $\left(\mathrm{AOS}=8.956-1.126 \times \Delta \mathrm{E}_{\mathrm{Mn} 3 \mathrm{~s}}\right)$. $^{43,49-52,54,55}$ The splitting originates from the exchange coupling between 3 s hole and $3 \mathrm{~d}$ electrons and proportional to $(2 S+1)$, where $S$ is the spin of $3 d$ ground state electron configuration, ${ }^{55,56}$ where the lower oxidation states of the manganese centers cause a bigger splitting between M3s main and satellite peaks. ${ }^{55,56}$ Table 3 summarizes $\Delta \mathrm{E}_{\mathrm{Mn} 3 \mathrm{~s}}$ values and resulting average oxidation states for $\mathrm{K}_{\mathrm{x}} \mathrm{Mn}_{8} \mathrm{O}_{16}$ materials. Notably, the average oxidation state for the samples are quite similar, 3.6, where only the sample with the highest potassium level showed an average oxidation state of 3.8 .

Fig. $3 \mathrm{X}$-ray Photoelectron spectra (XPS) of $\mathrm{K}_{\mathrm{x}} \mathrm{Mn}_{8} \mathrm{O}_{16}$ materials with
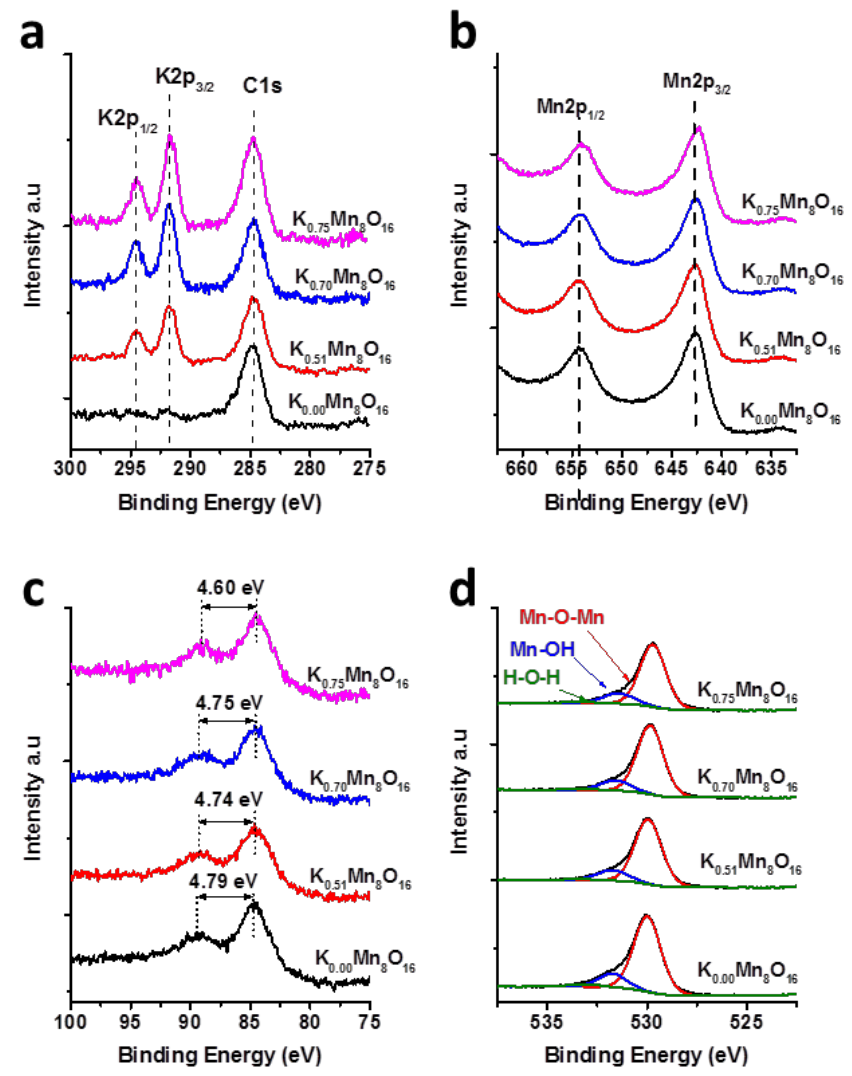

various $\mathrm{K}^{+}$amounts. (a) $\mathrm{K} 2 \mathrm{p}$ and $\mathrm{C} 1 \mathrm{~s}$, (b) Mn 2p, (c) Mn 3s, and (d) O $1 s$ spectral regions. $O$ 1s spectral region was deconvoluted into three chemical states; $\mathrm{Mn}-\mathrm{O}-\mathrm{Mn}, \mathrm{Mn}-\mathrm{OH}$, and $\mathrm{H}-\mathrm{O}-\mathrm{H}$ (physisorbed water). 
Table 3 The summary of XPS data of $\mathrm{K}_{\mathrm{x}} \mathrm{Mn}_{8} \mathrm{O}_{16}$ materials with various $\mathrm{K}^{+}$amounts

\begin{tabular}{|c|c|c|c|c|c|c|c|c|c|c|}
\hline \multirow[t]{2}{*}{ Sample } & \multicolumn{3}{|c|}{$\operatorname{Mn} 2 p(e V)$} & \multicolumn{3}{|c|}{ Mn 3s (eV) } & \multicolumn{3}{|c|}{ 01s } & \multirow{2}{*}{$\begin{array}{c}\text { Average } \\
\text { Oxidation State }\end{array}$} \\
\hline & $2 p_{3 / 2}$ & $2 p_{1 / 2}$ & $\Delta \mathrm{E}$ & $\mathrm{BE}_{1}{ }^{\mathrm{a}}$ & $\mathrm{BE}_{2}{ }^{\mathrm{a}}$ & $\Delta \mathrm{E}^{\mathrm{b}}$ & State $^{c}$ & $\mathrm{BE}(\mathrm{eV})$ & Area (\%) & \\
\hline \multirow[t]{3}{*}{$\mathrm{K}_{0.00} \mathrm{Mn}_{8} \mathrm{O}_{16}$} & 642.69 & 654.09 & 11.4 & 84.68 & 89.47 & 4.79 & $\mathrm{Mn}-\mathrm{O}-\mathrm{Mn}$ & 529.98 & 82 & 3.6 \\
\hline & & & & & & & $\mathrm{Mn}-\mathrm{O}-\mathrm{H}$ & 531.73 & 15 & \\
\hline & & & & & & & $\mathrm{H}-\mathrm{O}-\mathrm{H}$ & 533.12 & 3 & \\
\hline \multirow[t]{3}{*}{$\mathrm{K}_{0.51} \mathrm{Mn}_{8} \mathrm{O}_{16}$} & 642.73 & 654.11 & 11.38 & 84.61 & 89.36 & 4.75 & $\mathrm{Mn}-\mathrm{O}-\mathrm{Mn}$ & 529.93 & 83 & 3.6 \\
\hline & & & & & & & $\mathrm{Mn}-\mathrm{O}-\mathrm{H}$ & 531.72 & 16 & \\
\hline & & & & & & & $\mathrm{H}-\mathrm{O}-\mathrm{H}$ & 533.37 & 2 & \\
\hline \multirow[t]{3}{*}{$\mathrm{K}_{0.70} \mathrm{Mn}_{8} \mathrm{O}_{16}$} & 642.61 & 654.12 & 11.36 & 84.57 & 89.31 & 4.74 & $\mathrm{Mn}-\mathrm{O}-\mathrm{Mn}$ & 529.83 & 84 & 3.6 \\
\hline & & & & & & & $\mathrm{Mn}-\mathrm{O}-\mathrm{H}$ & 531.56 & 14 & \\
\hline & & & & & & & $\mathrm{H}-\mathrm{O}-\mathrm{H}$ & 533.35 & 2 & \\
\hline \multirow[t]{3}{*}{$\mathrm{K}_{0.75} \mathrm{Mn}_{8} \mathrm{O}_{16}$} & 642.45 & 654.05 & 11.44 & 84.49 & 89.09 & 4.60 & $\mathrm{Mn}-\mathrm{O}-\mathrm{Mn}$ & 529.7 & 82 & 3.8 \\
\hline & & & & & & & $\mathrm{Mn}-\mathrm{O}-\mathrm{H}$ & 531.41 & 16 & \\
\hline & & & & & & & $\mathrm{H}-\mathrm{O}-\mathrm{H}$ & 533.34 & 2 & \\
\hline
\end{tabular}

${ }^{a}$ Binding energies of two chemical states were obtained for $\mathrm{Mn} 3 \mathrm{~s}$ photoelectrons, ${ }^{\mathrm{b}} \Delta \mathrm{E}=\mathrm{BE}_{1}-\mathrm{B}_{2}$ Eof $\mathrm{Mn3s}$ photoelectrons, ${ }^{\mathrm{c}}$ three different chemical states of $\mathrm{O}$ as indicated, were obtained from 01s spectral region, and ${ }^{\mathrm{d}}$ Average oxidation states (AOS) were calculated from the $\triangle \mathrm{E}$ of Mn3s peaks (AOS $=8.956-$ $\left.1.126 \times \Delta \mathrm{E}_{(35)}\right)$.

O1s spectra of $\mathrm{K}_{\mathrm{x}} \mathrm{Mn}_{8} \mathrm{O}_{16}$ materials are shown in Fig. $3 \mathrm{~d}$ where the O1s spectral region is deconvoluted to three different oxygen species: (1) Mn-O-Mn lattice oxygen at 529.7-530.0 eV, (2) Mn-OH surface hydroxyls or defect-oxide at 531.4-531.7 eV, and (3) H-O-H surface adsorbed water at 531.1-533.4 eV. ${ }^{8,43,49,50,54,57-60 \quad \mathrm{~A}}$ relative area comparison of different oxygen constituents suggests that $>80 \%$ of oxygen in all $\mathrm{K}_{\mathrm{x}} \mathrm{Mn}_{8} \mathrm{O}_{16}$ samples is lattice oxygen, while surface adsorbed water $(\mathrm{H}-\mathrm{O}-\mathrm{H})$ content is $<3 \%$ (Table 3 ). High lattice oxygen content at the surface of $\alpha-\mathrm{MnO}_{2}$ materials can be attributed to the high post-synthesis annealing temperature of $400^{\circ} \mathrm{C}$. A prior report demonstrated that a heat treatment temperature at $300^{\circ} \mathrm{C}$ is sufficient to convert more than $70 \%$ of $\mathrm{Mn}$ $\mathrm{OH}$ to $\mathrm{Mn}-\mathrm{O}-\mathrm{Mn}^{43}$

\subsubsection{Electron Microscopy (SEM and HR-TEM)}

Morphology studies using SEM showed all the $\mathrm{K}_{\mathrm{x}} \mathrm{Mn}_{8} \mathrm{O}_{16}$ materials to have very similar shapes and surface features (Fig. 4 and Fig. S4). At low magnification, all $\mathrm{K}_{\mathrm{x}} \mathrm{Mn}_{8} \mathrm{O}_{16}$ samples had rounded shapes (1$5 \mu \mathrm{m})$ forming larger aggregates. At high magnification, it can be seen that the rounded micron sized particles are formed by high aspect ratio nanofibers, consistent with typical gross morphology of $\mathrm{K}_{\mathrm{x}} \mathrm{Mn}_{8} \mathrm{O}_{16}$ materials. ${ }^{9}, 16,22,24,43,54,58,61$

TEM experiments showed the nanorods to be uniformly dispersed with their growth direction along the [001] direction. The typical features of the $\mathrm{K}_{0.00} \mathrm{Mn}_{8} \mathrm{O}_{16}$ and $\mathrm{K}_{0.32} \mathrm{Mn}_{8} \mathrm{O}_{16}$ samples are shown in Fig. 5a,b and Fig. 5c,d, respectively, consisting of short, thin nanorods of similar size. For the $\mathrm{K}_{0.75} \mathrm{Mn}_{8} \mathrm{O}_{16}$ sample, as shown in Fig. $5 \mathrm{e}$ and Fig. $5 f$, the nanorods become much longer and wider, indicating the importance of $\mathrm{K}^{+}$ions in the process of nanorod growth. The corresponding diffractograms via fast Fourier transformation are embedded in the $\mathrm{K}_{0.00} \mathrm{Mn}_{8} \mathrm{O}_{16}$ and $\mathrm{K}_{0.32} \mathrm{Mn}_{8} \mathrm{O}_{16}$ high resolution TEM images Fig. $5 b$ and Fig. $5 d$, respectively. We compare two nanorods that share the same zone axis in crystal orientation. The edge area for the $\mathrm{K}_{0.00} \mathrm{Mn}_{8} \mathrm{O}_{16}$ nanorod is sharp and its interior exhibits considerable lattice disorder and defects, Fig. 5b. Only parts of the nanorods (as marked in red circles) appear to be highly crystalline. For the $\mathrm{K}^{+}$containing $\mathrm{K}_{0.32} \mathrm{Mn}_{8} \mathrm{O}_{16}$ and $\mathrm{K}_{0.75} \mathrm{Mn}_{8} \mathrm{O}_{16}$ samples, Fig. $5 \mathrm{~d}$ and Fig. $5 \mathrm{f}$, respectively, their edge regions are less well crystallized compared with their interiors. The
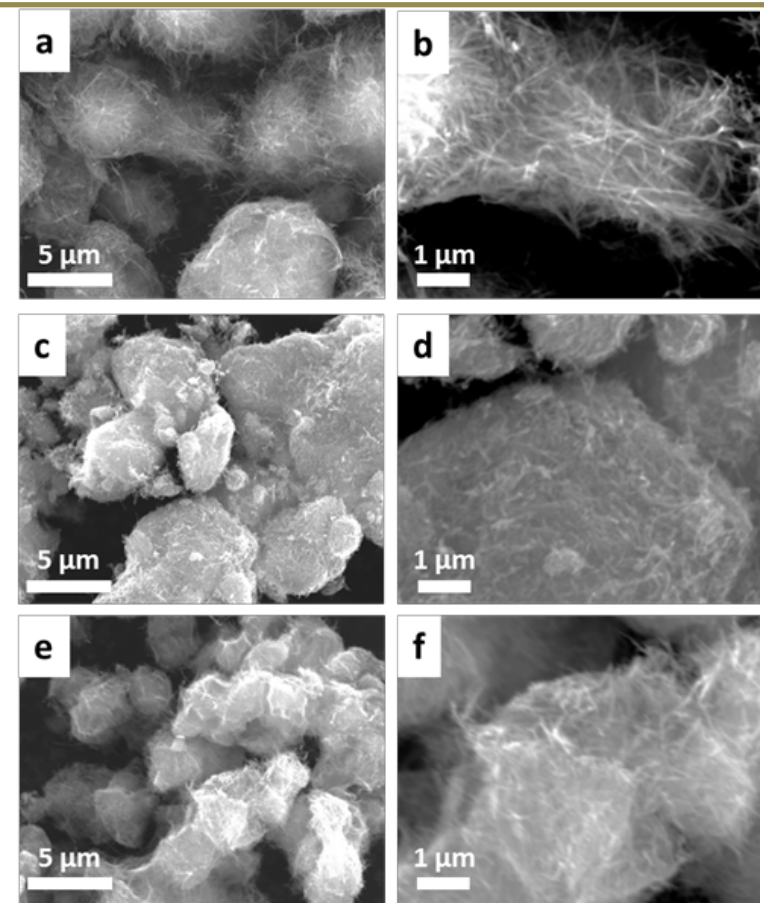

$\mathrm{K}_{0.32} \mathrm{Mn}_{8} \mathrm{O}_{16}$ sample has $1.5 \mathrm{~nm}$ surface layer, while $\mathrm{K}_{0.75} \mathrm{Mn}_{8} \mathrm{O}_{16}$ sample has an even larger surface layer ( $3 \mathrm{~nm}$ on average), indicating the defects prefer to accumulate at the edge locations for $\mathrm{K}^{+}$containing samples.

Fig. 4 SEM Images of (a), (b) $\mathrm{K}_{0.00} \mathrm{Mn}_{8} \mathrm{O}_{16}$, (c), (d) $\mathrm{K}_{0.32} \mathrm{Mn}_{8} \mathrm{O}_{16}$, and (e), (f) $\mathrm{K}_{0.75} \mathrm{Mn}_{8} \mathrm{O}_{16}$. The images were recorded at two different magnifications: (a), (c), (e) were at $5 \mathrm{kX}$ and (b), (d), (f) were at $15 \mathrm{kX}$. See Fig. S4 for SEM images of $\mathrm{K}_{0.51} \mathrm{Mn}_{8} \mathrm{O}_{16}$ and $\mathrm{K}_{0.70} \mathrm{Mn}_{8} \mathrm{O}_{16}$. 

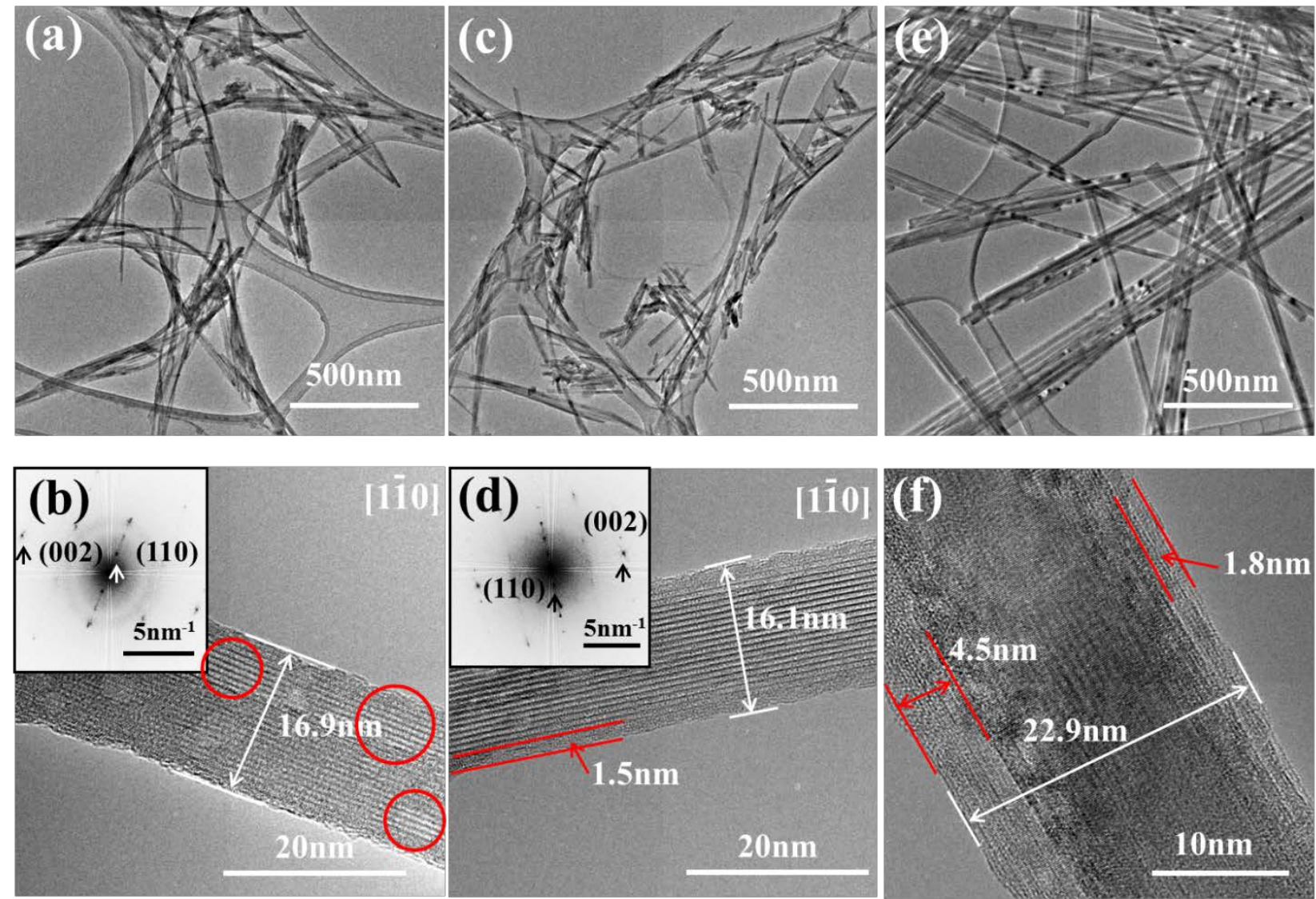

Fig. 5 Morphologies and micro-structures of cryptomelane nanorods with different contents of $\mathrm{K}^{+}$ions. (a), (b) $\mathrm{K}_{0.00} \mathrm{Mn}_{8} \mathrm{O}_{16}$ sample; (c), (d) $\mathrm{K}_{0.32} \mathrm{Mn}_{8} \mathrm{O}_{16}$ sample; and (e), (f) $\mathrm{K}_{0.75} \mathrm{Mn}_{8} \mathrm{O}_{16}$ sample. The two nanorods in (b) and (d) are recorded from the same orientation and the diffractograms of fast Fourier transform (FFT) are imbedded as insets. Most areas of the nanorod in (b) and (d) show lattice disorder, except the regions marked by the red circles. For $\mathrm{K}^{+}$containing samples, the surface regions, indicated by the red lines in (d) and ( $f$ ), are less ordered.

\subsection{Electrochemical Characterization}

\subsubsection{Cyclic Voltammetry}

The electrochemistry of the $\mathrm{K}_{\mathrm{x}} \mathrm{Mn}_{8} \mathrm{O}_{16}$ materials with different $\mathrm{K}^{+}$ content was probed by cyclic voltammetry $(\mathrm{CV})$, galvanostatic charge-discharge, rate capability, and galvanostatic intermittent titration technique (GITT) methods. CV was performed in the voltage range of 1.5-4.0 V with a scan rate of $0.1 \mathrm{mV} / \mathrm{s}$ (Fig. 6 and Fig. S5) using the $\mathrm{K}_{0.00} \mathrm{Mn}_{8} \mathrm{O}_{16}, \mathrm{~K}_{0.32} \mathrm{Mn}_{8} \mathrm{O}_{16}$, and $\mathrm{K}_{0.75} \mathrm{Mn}_{8} \mathrm{O}_{16}$ materials. Cathodic-anodic peak positions and the peak separations are reported in Table 4. Both cathodic and anodic peaks become sharper and more well-defined with decreasing potassium content (Fig. 6d). The $\mathrm{K}^{+}$free $\mathrm{K}_{0.00} \mathrm{Mn}_{8} \mathrm{O}_{16}$ sample exhibits two sharp cathodic (2.77 and $2.62 \mathrm{~V}$ ) and one sharp anodic peak at 3.05V. In the second cycle, $\mathrm{K}_{0.00} \mathrm{Mn}_{8} \mathrm{O}_{16}$ adopts a single cathodic peak centered at 2.67. The changes in peak position and current are very small for the cathodic peak at the second cycle for $\mathrm{K}_{0.00} \mathrm{Mn}_{8} \mathrm{O}_{16}$. More detailed examination of the $\mathrm{CV}$ reveals a notable trend in the cathodic and anodic peak separation as a function of potassium content in $\mathrm{K}_{\mathrm{x}} \mathrm{Mn}_{8} \mathrm{O}_{16}$ samples. In both the first and second cycles, $\mathrm{K}_{0.00} \mathrm{Mn}_{8} \mathrm{O}_{16}$ has the smallest peak separation of $0.28 \mathrm{~V}$ and $0.41 \mathrm{~V}$, respectively, indicating a higher level of electrochemical reversibility for $\mathrm{K}_{0.00} \mathrm{Mn}_{8} \mathrm{O}_{16}$. With increasing potassium content the anodic peak gets broader and a shoulder emerges at $3.21 \mathrm{~V}$ for the $\mathrm{K}_{0.75} \mathrm{Mn}_{8} \mathrm{O}_{16}$ sample.
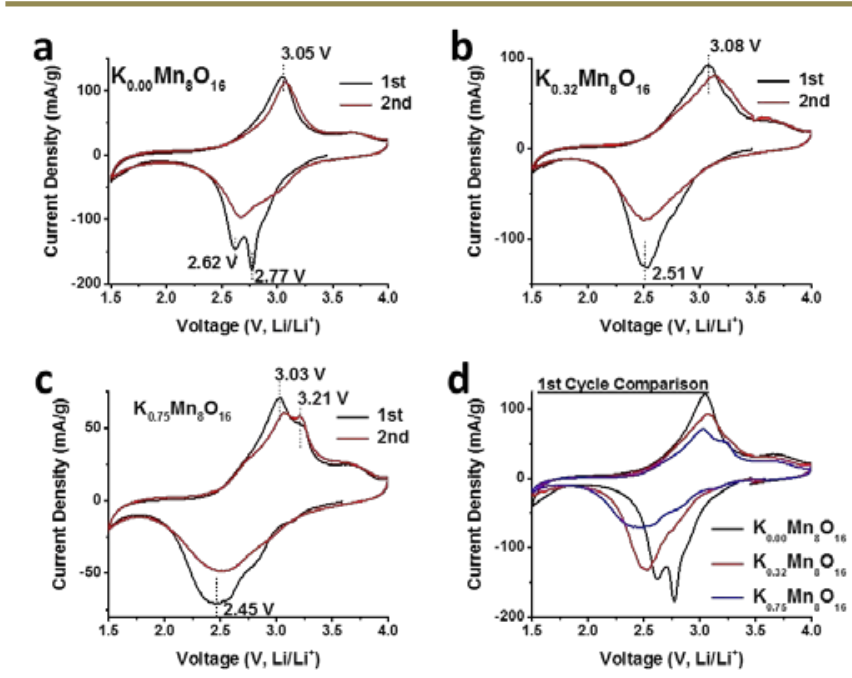

Fig. 6 Cyclic Voltammetry of (a) $\mathrm{K}_{0.00} \mathrm{Mn}_{8} \mathrm{O}_{16}$, (b) $\mathrm{K}_{0.32} \mathrm{Mn}_{8} \mathrm{O}_{16}$, and (c) $\mathrm{K}_{0.75} \mathrm{Mn}_{8} \mathrm{O}_{16}$. (d) Comparison of $1^{\text {st }}$ cycles. See also Fig. $\mathrm{S} 5$ for cyclic voltammetry of $\mathrm{K}_{0.51} \mathrm{Mn}_{8} \mathrm{O}_{16}$ and $\mathrm{K}_{0.75} \mathrm{Mn}_{8} \mathrm{O}_{16}$. Scan rate is $0.1 \mathrm{mV} / \mathrm{s}$. 

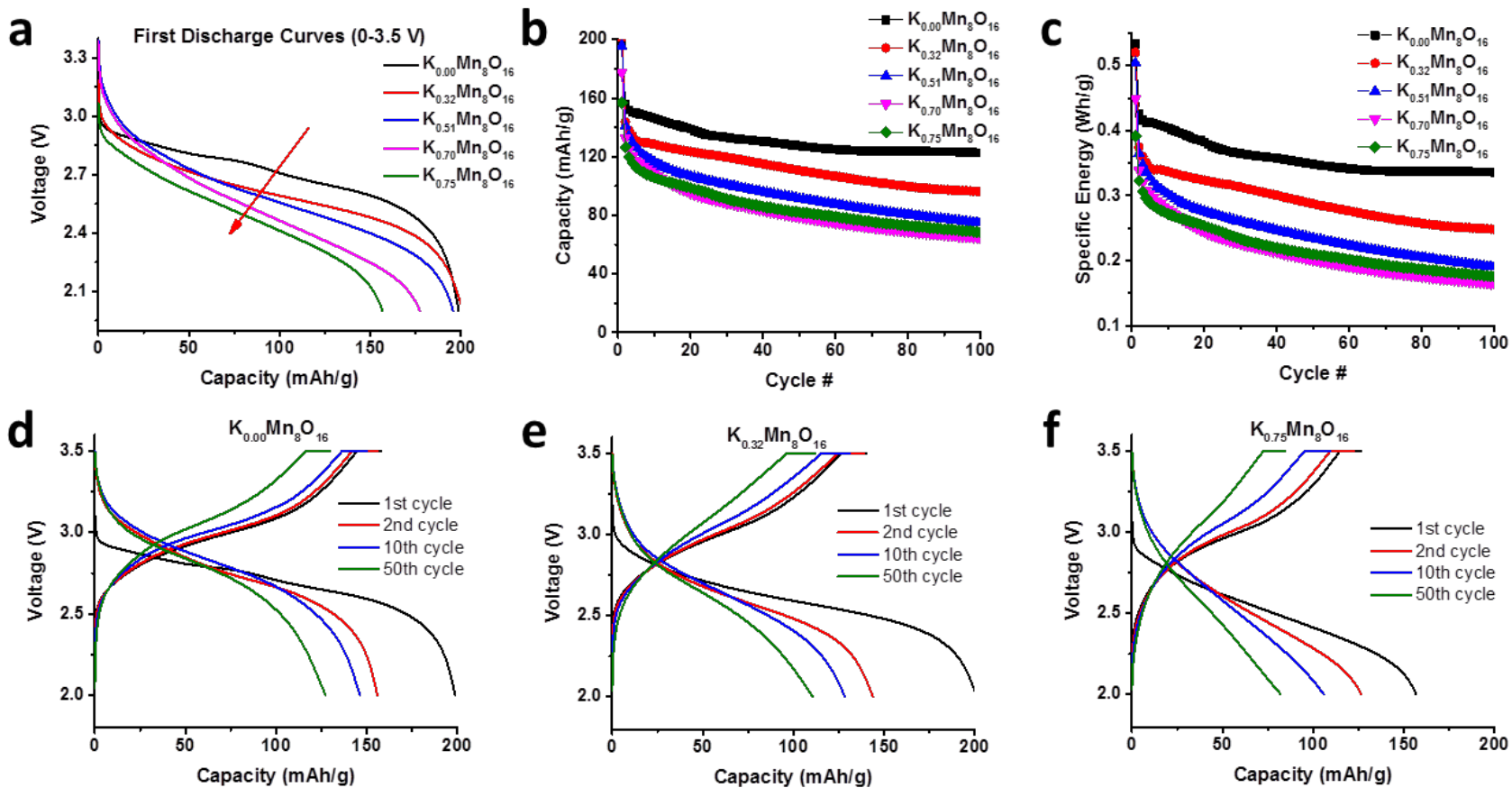

Fig. 7 (a) $1^{\text {st }}$ discharge profiles, (b) Evolution of discharge capacity (mAh/g) over 100 cycles, and (c) evolution of specific energy (Wh/g) over 100 cycles for samples with varying $\mathrm{K}^{+}$content; $\mathrm{K}_{0.00} \mathrm{Mn}_{8} \mathrm{O}_{16}, \mathrm{~K}_{0.32} \mathrm{Mn}_{8} \mathrm{O}_{16}, \mathrm{~K}_{0.51} \mathrm{Mn}_{8} \mathrm{O}_{16}, \mathrm{~K}_{0.70} \mathrm{Mn}_{8} \mathrm{O}_{16}$, and $\mathrm{K}_{0.75} \mathrm{Mn}_{8} \mathrm{O}_{16}$. Representative discharge profiles at cycles 1, 2, 10, and 50 for (d) $\mathrm{K}_{0.00} \mathrm{Mn}_{8} \mathrm{O}_{16}$, (e) $\mathrm{K}_{0.32} \mathrm{Mn}_{8} \mathrm{O}_{16}$, and (f) $\mathrm{K}_{0.75} \mathrm{Mn}_{8} \mathrm{O}_{16}$. The cells were discharged-charged at a rate of $50 \mathrm{~mA} / \mathrm{g}$. See supplementary Fig. $\mathrm{S} 6$ for discharge profiles of $\mathrm{K}_{0.51} \mathrm{Mn}_{8} \mathrm{O}_{16}$ and $\mathrm{K}_{0.70} \mathrm{Mn}_{8} \mathrm{O}_{16}$.

Table 4 Cathodic $\left(E_{p c}\right)$ and Anodic $\left(E_{p a}\right)$ peak positions of $\mathrm{K}_{\mathrm{x}} \mathrm{Mn}_{8} \mathrm{O}_{16}$ materials with various $\mathrm{K}$ amount

\begin{tabular}{crrllll}
\hline \multicolumn{1}{c}{ Sample } & \multicolumn{3}{c}{$1^{\text {st }}$ CV Cycle } & \multicolumn{3}{c}{$2^{\text {nd }}$ CV Cycle } \\
\cline { 2 - 8 } & $\mathrm{E}_{\mathrm{pc}}$ & $\mathrm{E}_{\mathrm{pa}}$ & $\Delta \mathrm{E}$ & $\mathrm{E}_{\mathrm{pc}}$ & $\mathrm{E}_{\mathrm{pa}}$ & $\Delta \mathrm{E}$ \\
& $(\mathrm{V})$ & $(\mathrm{V})$ & $(\mathrm{V})$ & $(\mathrm{V})$ & $(\mathrm{V})$ & $(\mathrm{V})$ \\
$\mathrm{K}_{0.00} \mathrm{Mn}_{8} \mathrm{O}_{16}$ & 2.77 & 3.05 & 0.28 & 2.67 & 3.08 & 0.41 \\
$\mathrm{~K}_{0.32} \mathrm{Mn}_{8} \mathrm{O}_{16}$ & 2.52 & 3.06 & 0.54 & 2.53 & 3.12 & 0.59 \\
$\mathrm{~K}_{0.51} \mathrm{Mn}_{8} \mathrm{O}_{16}$ & 2.50 & 3.04 & 0.54 & 2.52 & 3.09 & 0.57 \\
$\mathrm{~K}_{0.70} \mathrm{Mn}_{8} \mathrm{O}_{16}$ & 2.45 & 3.03 & 0.58 & 2.47 & 3.10 & 0.63 \\
$\mathrm{~K}_{0.75} \mathrm{Mn}_{8} \mathrm{O}_{16}$ & 2.45 & 3.03 & 0.58 & 2.50 & 3.08 & 0.58 \\
\hline
\end{tabular}

\subsubsection{Galvanostatic Charge-discharge Test}

Galvanostatic cycling data were collected for 100 cycles at a current level of $50 \mathrm{~mA} / \mathrm{g}$ (Fig. 7 and Fig. S6). The initial discharge profiles of $\mathrm{K}_{\mathrm{x}} \mathrm{Mn}_{8} \mathrm{O}_{16}$ materials with various potassium content show notable differences (Fig. 7a). All $\mathrm{K}_{\mathrm{x}} \mathrm{Mn}_{8} \mathrm{O}_{16}$ samples demonstrate s-shaped discharge profiles with a sloped plateau consistent with previously reported $\mathrm{K}_{x} \mathrm{Mn}_{8} \mathrm{O}_{16}$ materials. ${ }^{16,}{ }^{54,}$ 62-64 $\mathrm{High} \mathrm{K}^{+}$containing $\mathrm{K}_{0.70} \mathrm{Mn}_{8} \mathrm{O}_{16}$ and $\mathrm{K}_{0.75} \mathrm{Mn}_{8} \mathrm{O}_{16}$ samples have smaller initial discharge capacities compared to low $\mathrm{K}^{+}$containing samples $\mathrm{K}_{0.00} \mathrm{Mn}_{8} \mathrm{O}_{16}$, $\mathrm{K}_{0.32} \mathrm{Mn}_{8} \mathrm{O}_{16}$, and $\mathrm{K}_{0.51} \mathrm{Mn}_{8} \mathrm{O}_{16}, 177$ and $157 \mathrm{mAh} / \mathrm{g}$, respectively. The
$\mathrm{K}^{+}$free $\mathrm{K}_{0.00} \mathrm{Mn}_{8} \mathrm{O}_{16}$ demonstrates two plateaus at 2.8 and $2.66 \mathrm{~V}$ suggesting multiple inequivalent sites for lithium occupation. However, the second plateau is no longer apparent after the first cycle where the $\mathrm{K}_{0.00} \mathrm{Mn}_{8} \mathrm{O}_{16}$ sample adopts an s-shaped discharge curve with a single sloped plateau at $2.8 \mathrm{~V}$ (Fig. 7d). S-shaped discharge curves with 2 plateaus have been reported for chemically lithiated $\mathrm{Mn}_{8} \mathrm{O}_{16}$ materials. ${ }^{13,14}$ However, central metal cation free $\mathrm{Mn}_{8} \mathrm{O}_{16}$ demonstrated a single sloped discharge plateau. ${ }^{13,14,48}$ The voltage of the discharge plateau decreases systematically with increasing $\mathrm{K}^{+}$content (Fig. 7a), where the $\mathrm{K}_{0.00} \mathrm{Mn}_{8} \mathrm{O}_{16}, \mathrm{~K}_{0.32} \mathrm{Mn}_{8} \mathrm{O}_{16}$, $\mathrm{K}_{0.51} \mathrm{Mn}_{8} \mathrm{O}_{16}, \mathrm{~K}_{0.70} \mathrm{Mn}_{8} \mathrm{O}_{16}$, and $\mathrm{K}_{0.75} \mathrm{Mn}_{8} \mathrm{O}_{16}$ have discharge voltage plateaus of 2.80, 2.62, 2.58, 2.53, and 2.50V, respectively.

All the $\mathrm{K}_{\mathrm{x}} \mathrm{Mn}_{8} \mathrm{O}_{16}$ samples showed low Coulombic efficiencies (70-80 \%) at cycle 1 , and the efficiencies increased to 100 \% after cycle 2 (Fig. S7). Low initial Coulombic efficiency of $\alpha-\mathrm{MnO}_{2}$ has also been observed in previous literature, which may be correlated with trapped $\mathrm{Li}^{+}$ions in the tunnels. ${ }^{13,14,16,62,63}$ After 100 cycles, the discharge capacities of the $\mathrm{K}_{0.00} \mathrm{Mn}_{8} \mathrm{O}_{16}, \mathrm{~K}_{0.32} \mathrm{Mn}_{8} \mathrm{O}_{16}, \mathrm{~K}_{0.51} \mathrm{Mn}_{8} \mathrm{O}_{16}$, $\mathrm{K}_{0.70} \mathrm{Mn}_{8} \mathrm{O}_{16}$, and $\mathrm{K}_{0.75} \mathrm{Mn}_{8} \mathrm{O}_{16}$ were $123,96,75,66$, and $68 \mathrm{mAh} / \mathrm{g}$, respectively. Thus, $\mathrm{K}_{0.00} \mathrm{Mn}_{8} \mathrm{O}_{16}$ delivers $28 \%$ more capacity than $\mathrm{K}_{0.32} \mathrm{Mn}_{8} \mathrm{O}_{16}$ and $79 \%$ more capacity than $\mathrm{K}_{0.75} \mathrm{Mn}_{8} \mathrm{O}_{16}$ after 100 cycles. In general, the lower potassium containing $\mathrm{K}_{\mathrm{x}} \mathrm{Mn}_{8} \mathrm{O}_{16}$ materials show better capacity retention (Fig. $7 \mathrm{~b}$ ). The capacity loss is the highest in the first cycle $(\geq 20 \%)$ for all $\mathrm{K}_{x} \mathrm{Mn}_{8} \mathrm{O}_{16}$ samples. After the first cycle, the capacity loss is only $\sim 18 \%$ for $\mathrm{K}_{0.00} \mathrm{Mn}_{8} \mathrm{O}_{16}$ over the following 99 cycles whereas the losses are $33 \%$ and $47 \%$ 
for higher potassium containing $\mathrm{K}_{0.32} \mathrm{Mn}_{8} \mathrm{O}_{16}$ and $\mathrm{K}_{0.75} \mathrm{Mn}_{8} \mathrm{O}_{16}$ materials, respectively.

Due to higher voltage plateaus of $\mathrm{K}_{\mathrm{x}} \mathrm{Mn}_{8} \mathrm{O}_{16}$ samples with lower $\mathrm{K}^{+}$content, we also report the evolution of specific energies (Capacity $\mathrm{x}$ Voltage) of $\mathrm{K}_{\mathrm{x}} \mathrm{Mn}_{8} \mathrm{O}_{16}$ samples with battery cycling (Fig. 7c). Among all, $\mathrm{K}_{0.00} \mathrm{Mn}_{8} \mathrm{O}_{16}$ delivers the highest specific energies of $533 \mathrm{Wh} / \mathrm{kg}$ initially and $336 \mathrm{Wh} / \mathrm{kg}$ at the end of $100^{\text {th }}$ cycle. Specific energies of $\mathrm{K}_{\mathrm{x}} \mathrm{Mn}_{8} \mathrm{O}_{16}$ samples decrease with increasing $\mathrm{K}^{+}$content reaching the lowest values for $\mathrm{K}_{0.75} \mathrm{Mn}_{8} \mathrm{O}_{16}$ with specific energies of $392 \mathrm{Wh} / \mathrm{kg}$ at the first and $175 \mathrm{Wh} / \mathrm{kg}$ at the end of $100^{\text {th }}$ cycle. Charge-discharge curves (at $1^{\text {st }}, 2^{\text {nd }}, 10^{\text {th }}$, and $50^{\text {th }}$ cycles) of $\mathrm{K}_{0.00} \mathrm{Mn}_{8} \mathrm{O}_{16}$ (Fig. 7d), $\mathrm{K}_{0.32} \mathrm{Mn}_{8} \mathrm{O}_{16}$ (Fig. 7e), and $\mathrm{K}_{0.75} \mathrm{Mn}_{8} \mathrm{O}_{16}$ (Fig. 7f) also demonstrate different characteristics with varying $\mathrm{K}^{+}$content. $\mathrm{K}_{0.00} \mathrm{Mn}_{8} \mathrm{O}_{16}$ preserves s-shaped discharge curves with one plateau at around $\sim 2.8 \mathrm{~V}$ even after 50 cycles. However, the discharge curve evolves to a single sloping profile for $\mathrm{K}_{0.51} \mathrm{Mn}_{8} \mathrm{O}_{16}, \mathrm{~K}_{0.70} \mathrm{Mn}_{8} \mathrm{O}_{16}$, and $\mathrm{K}_{0.75} \mathrm{Mn}_{8} \mathrm{O}_{16}$, indicative of a single-phase insertion electrode for high $\mathrm{K}^{+}$containing $\mathrm{K}_{\mathrm{x}} \mathrm{Mn}_{8} \mathrm{O}_{16}$ samples (Fig. $\mathrm{S} 6$ and Fig. $7 \mathrm{f}$ ).

In concert, these results indicate that the potassium free $\mathrm{K}_{0.00} \mathrm{Mn}_{8} \mathrm{O}_{16}$ cathode material prepared here displays higher capacity, higher specific energy, and improved capacity retention relative to its potassium containing counterparts. Notably, the discharge capacity and capacity retention of our $\mathrm{K}_{0.00} \mathrm{Mn}_{8} \mathrm{O}_{16}$ prepared by a hydrothermal route is significantly better than previously reported tunnel metal cation free $\mathrm{Mn}_{8} \mathrm{O}_{16}$ materials prepared by acid digestion and ozone oxidation. ${ }^{13,14,48}$ An initial discharge capacity of $\sim 60 \mathrm{mAh} / \mathrm{g}$ for potassium free $\mathrm{Mn}_{8} \mathrm{O}_{16}$ prepared by ozone oxidation was reported. ${ }^{48}$ Although $\mathrm{K}^{+}$free $\mathrm{Mn}_{8} \mathrm{O}_{16}$ prepared by acid digestion showed a higher initial discharge capacity of $218 \mathrm{mAh} / \mathrm{g}$ compared to our $\mathrm{K}_{0.00} \mathrm{Mn}_{8} \mathrm{O}_{16}(199 \mathrm{mAh} / \mathrm{g})$, its capacity faded rapidly to $136 \mathrm{mAh} / \mathrm{g}$ after 10 cycles. $^{13,14}$ The higher initial discharge capacity of the $\mathrm{K}^{+}$free $\mathrm{Mn}_{8} \mathrm{O}_{16}$ prepared by acid digestion may be due to a higher manganese average oxidation state (AOS) in those samples. ${ }^{65-67}$

\subsubsection{Rate Capability Test}

The effect of the tunnel $\mathrm{K}^{+}$on the charge-discharge rates is investigated by comparing the electrochemistry of $\mathrm{K}_{\mathrm{x}} \mathrm{Mn}_{8} \mathrm{O}_{16}$ with no potassium $\left(\mathrm{K}_{0.00} \mathrm{Mn}_{8} \mathrm{O}_{16}\right)$, low potassium $\left(\mathrm{K}_{0.32} \mathrm{Mn}_{8} \mathrm{O}_{16}\right)$, and high potassium $\left(\mathrm{K}_{0.75} \mathrm{Mn}_{8} \mathrm{O}_{16}\right)$ on a 40 cycle rate test where the current was changed after every 5 cycles (Fig. 8). At the lowest rate (10 $\mathrm{mA} / \mathrm{g}$ ), all $\mathrm{K}_{\mathrm{x}} \mathrm{Mn}_{8} \mathrm{O}_{16}$ samples regardless of $\mathrm{K}^{+}$content showed similar capacities all above $200 \mathrm{mAh} / \mathrm{g}$. As the discharge current density increased, the potassium free $\mathrm{K}_{0.00} \mathrm{Mn}_{8} \mathrm{O}_{16}$ and $\mathrm{K}_{0.32} \mathrm{Mn}_{8} \mathrm{O}_{16}$ materials deliver higher capacities than the $\mathrm{K}_{0.75} \mathrm{Mn}_{8} \mathrm{O}_{16}$ material. At $400 \mathrm{~mA} / \mathrm{g}$ the $\mathrm{K}_{0.00} \mathrm{Mn}_{8} \mathrm{O}_{16}, \mathrm{~K}_{0.32} \mathrm{Mn}_{8} \mathrm{O}_{16}$, and $\mathrm{K}_{0.75} \mathrm{Mn}_{8} \mathrm{O}_{16}$ samples deliver capacities of 115,99 , and $83 \mathrm{mAh} / \mathrm{g}$, respectively, where $\mathrm{K}_{0.00} \mathrm{Mn}_{8} \mathrm{O}_{16}$ delivers $39 \%$ more capacity than $\mathrm{K}_{0.75} \mathrm{Mn}_{8} \mathrm{O}_{16}$ at this rate. When the current density was decreased to $10 \mathrm{~mA} / \mathrm{g}$, $\mathrm{K}_{0.00} \mathrm{Mn}_{8} \mathrm{O}_{16}$ delivered $17 \%$ more capacity than $\mathrm{K}_{0.75} \mathrm{Mn}_{8} \mathrm{O}_{16}$ (131 vs. $112 \mathrm{mAh} / \mathrm{g})$.

\subsubsection{GITT Test}

The effect of $\mathrm{K}^{+}$content on the lithium ion diffusion in $\mathrm{K}_{\mathrm{x}} \mathrm{Mn}_{8} \mathrm{O}_{16}$ materials was further investigated using the galvanostatic intermittent titration technique (GITT) (Fig. 9a). The GITT technique is based on chronopotentiometry, where the cathode is subjected to $\mathrm{Li}^{+}$insertion/extraction by applying a constant current for a short period of time followed by an open circuit rest period often used to

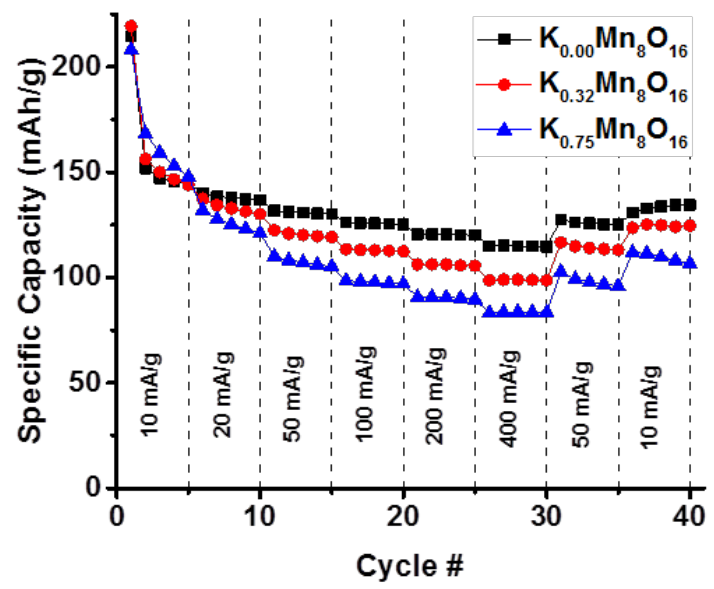

determine effective lithium ion diffusion, $D_{\mathrm{Lit}}$, in cathode materials. ${ }^{68-72} \mathrm{D}_{\mathrm{Li}+}$ can be derived from the potential responses to Fig. 8 Rate capability at various current densities (in the order of 10 , $20,50,100,200,400,50$, and $10 \mathrm{~mA} / \mathrm{g}$ ) of $\mathrm{K}_{0.00} \mathrm{Mn}_{8} \mathrm{O}_{16}, \mathrm{~K}_{0.32} \mathrm{Mn}_{8} \mathrm{O}_{16}$, and $\mathrm{K}_{0.75} \mathrm{Mn}_{8} \mathrm{O}_{16}$.
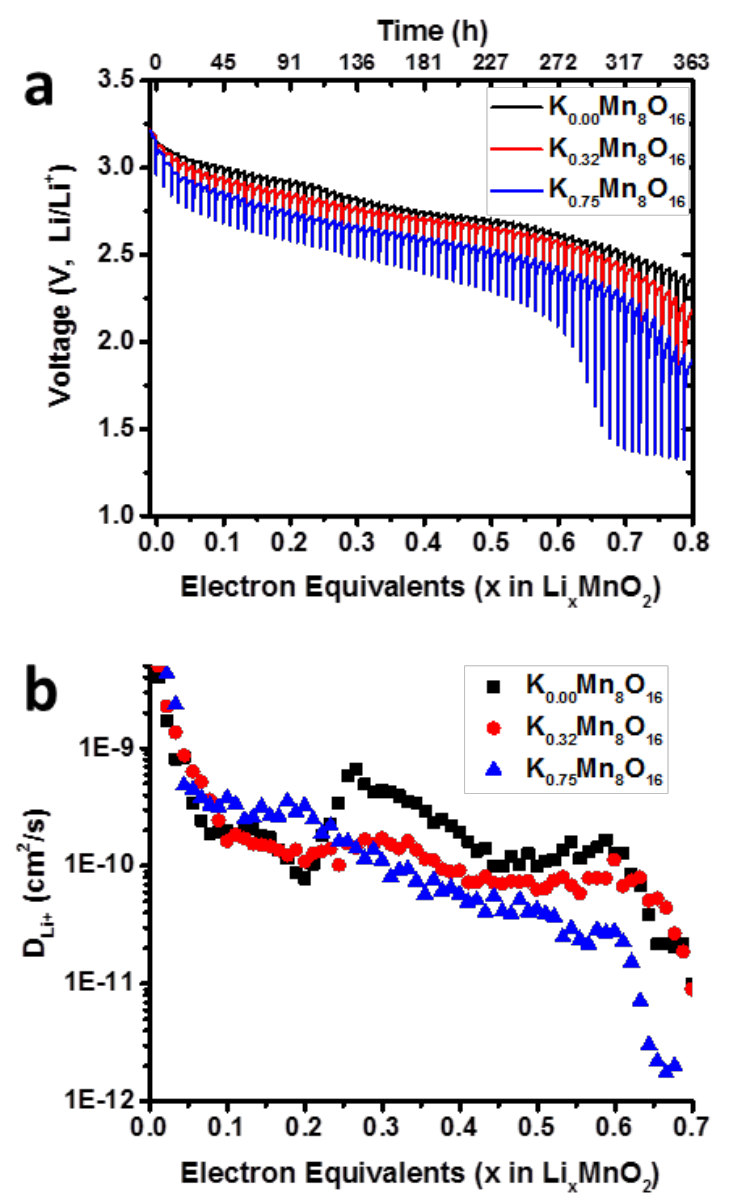

Fig. 9 (a) Galvanostatic Intermittent Titration Technique (GITT) plots and (b) Diffusion coefficient plots of $\mathrm{K}_{0.00} \mathrm{Mn}_{8} \mathrm{O}_{16}, \mathrm{~K}_{0.32} \mathrm{Mn}_{8} \mathrm{O}_{16}$, and $\mathrm{K}_{0.75} \mathrm{Mn}_{8} \mathrm{O}_{16}$. $100 \mathrm{~mA} / \mathrm{g}$ pulse current for $2 \mathrm{~min}$ followed by $5 \mathrm{~h}$ rest between the pulses. 

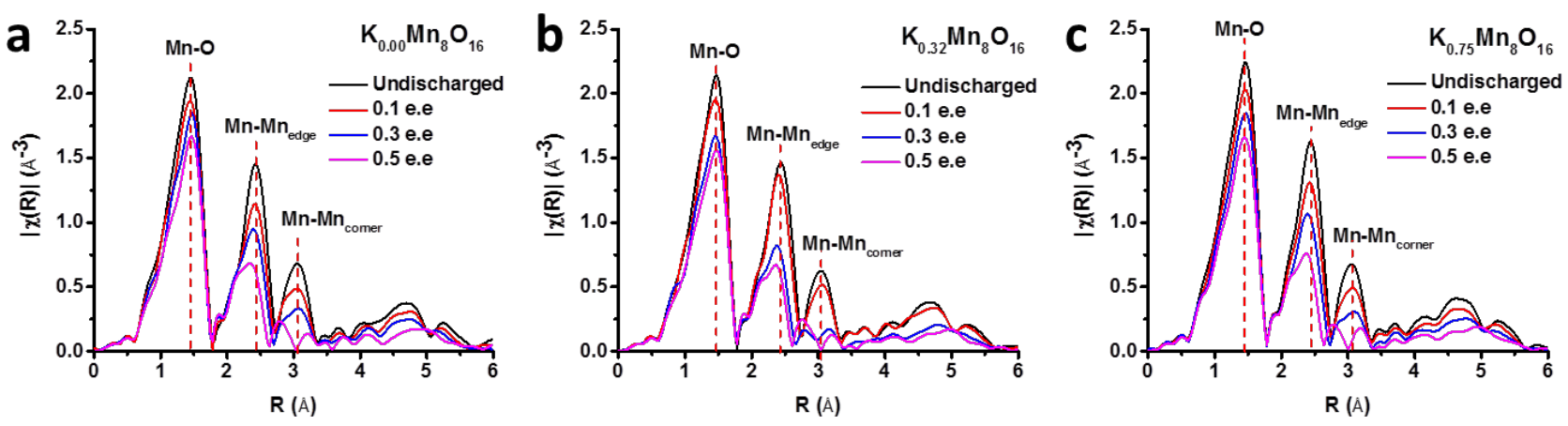

Fig. 10 EXAFS spectra for (a) $\mathrm{K}_{0.00} \mathrm{Mn}_{8} \mathrm{O}_{16}$, (b) $\mathrm{K}_{0.32} \mathrm{Mn}_{8} \mathrm{O}_{16}$, and (c) $\mathrm{K}_{0.75} \mathrm{Mn}_{8} \mathrm{O}_{16}$ at 0 (undischarged), 0.1, 0.3, and 0.5 lithiation levels. Electron equivalent (e.e.) numbers are reported per $\mathrm{MnO}_{2}$ unit.

constant current pulses using Fick's second law of diffusion using the following equation ${ }^{72,73}$ :

$D_{L i+}=\frac{4}{\pi}\left(\frac{m_{B} V_{m}}{M_{B} A}\right)^{2}\left(\frac{\Delta E_{S}}{\tau\left(d E_{\tau} / d \sqrt{\tau}\right)}\right)^{2}, \quad \tau \ll \frac{L^{2}}{D_{L i}}$

In the equation, $m_{B}$ is the mass of active material, $M_{B}$ and $V_{M}$ are the molar mass and volume respectively, $A$ is the electrode area, and $L$ is the electrode thickness. The voltage response (Fig. 9a) and calculated $D_{\mathrm{Li}}$ are reported in Fig. $9 \mathrm{~b}$. $\mathrm{D}_{\mathrm{Li}+}$ numbers range from $5 \mathrm{x}$ $10^{-8}$ to $1.7 \times 10^{-12} \mathrm{~cm}^{2} \mathrm{~s}^{-1}$ in the 0 to 0.7 electron equivalents range (per $\mathrm{MnO}_{2}$ unit), in good agreement with previously reported $\mathrm{D}_{\mathrm{Li}+}$ values for $\mathrm{K}_{\mathrm{x}} \mathrm{Mn}_{8} \mathrm{O}_{16}$ materials. ${ }^{20,54}$ Below 0.1 electron equivalent per $\mathrm{MnO}_{2}$ unit, all $\mathrm{K}_{\mathrm{x}} \mathrm{Mn}_{8} \mathrm{O}_{16}$ samples have similar $\mathrm{D}_{\text {Li+ }}$ values, where $\mathrm{D}_{\mathrm{Li}+}$ decrease by almost an order of magnitude to $\sim 5 \times 10^{-10} \mathrm{~cm}^{2} \mathrm{~s}^{-1}$. Between 0.1 to $\sim 0.2$ e.e., $\mathrm{D}_{\mathrm{Li}+}$ values remain fairly constant for $\mathrm{K}_{0.75} \mathrm{Mn}_{8} \mathrm{O}_{16}$, consistent with our previously reported $\mathrm{D}_{\mathrm{Li+}}$ results for fibrous $\mathrm{K}_{\mathrm{x}} \mathrm{Mn}_{8} \mathrm{O}_{16}$ materials with a similar $\mathrm{K}^{+}$content. ${ }^{54}$ However, $\mathrm{D}_{\mathrm{Li}+}$ values decrease to $\sim 10^{-10} \mathrm{~cm}^{2} \mathrm{~s}^{-1}$ for low $\mathrm{K}^{+}$containing $\mathrm{K}_{0.32} \mathrm{Mn}_{8} \mathrm{O}_{16}$ and $\mathrm{K}_{0.00} \mathrm{Mn}_{8} \mathrm{O}_{16}$. Relatively high $\mathrm{D}_{\text {Lit }}$ value at early stages of discharge are also consistent with previous in-situ TEM and DFT calculations, ${ }^{17,47,74}$ where, lithium first occupies $8 \mathrm{~h}$ sites in $2 \times 2$ tunnels causing no or minimal changes in lattice parameters. Theoretically, all thermodynamically favourable $8 \mathrm{~h}$ sites in $2 \times 2$ tunnels are occupied at 0.25 electron equivalents and no geometrical (or volume) change is expected below 0.25 electron equivalents ${ }^{17}$. Therefore, one could predict higher $D_{\mathrm{Li}}$ values below 0.25 e.e. Between 0.2 to 0.5 e.e. per $\mathrm{MnO}_{2}$ unit, the $\mathrm{D}_{\mathrm{Li}}$ values of $\mathrm{K}_{\mathrm{x}} \mathrm{Mn}_{8} \mathrm{O}_{16}$ materials differ as a function of $\mathrm{K}^{+}$content. In order to confirm this change in $\mathrm{D}_{\mathrm{Li}+}$ values between 0.2 to 0.4 e.e. per $\mathrm{MnO}_{2}$ unit, we repeated the GITT experiment with different discharge and rest settings ( $40 \mathrm{~mA} / \mathrm{g}$ discharge for $10 \mathrm{~min}$ and $12 \mathrm{~h}$ rest) (Fig. S9). The results were consistent and similar for both tests. The significantly higher $\mathrm{D}_{\mathrm{Li}}$ observed for the $\mathrm{K}_{0.00} \mathrm{Mn}_{8} \mathrm{O}_{16}$ material with higher water content per formula unit may relate to formation of $\mathrm{Li}_{2} \mathrm{O}$ species within the tunnels by the reaction of tunnel water and $\mathrm{Li}^{+}$ions. Prior studies on chemically lithiated $\alpha-\mathrm{MnO}_{2}$ samples proposed formation of $\mathrm{Li}_{2} \mathrm{O}$ species in the tunnels which stabilize the tunnel structure and facilitate Li ion diffusion. ${ }^{13,14,29,48}$

\section{3 Mn K-Edge Extended X-Ray Absorption Fine Structure Analysis}

The local structural changes upon electrochemical lithiation were studied by extended $x$-ray absorption fine structure (EXAFS) spectroscopy. The k-space and fitted r-space spectra of undischarged and discharged $\mathrm{K}_{0.00} \mathrm{Mn}_{8} \mathrm{O}_{16}, \mathrm{~K}_{0.32} \mathrm{Mn}_{8} \mathrm{O}_{16}$, and $\mathrm{K}_{0.75} \mathrm{Mn}_{8} \mathrm{O}_{16}$ samples are reported in Fig. S10, S11, and $\mathrm{S} 12$, respectively. EXAFS spectra of the $\mathrm{K}_{0.00} \mathrm{Mn}_{8} \mathrm{O}_{16}, \mathrm{~K}_{0.32} \mathrm{Mn}_{8} \mathrm{O}_{16}$, and $\mathrm{K}_{0.75} \mathrm{Mn}_{8} \mathrm{O}_{16}$ samples show characteristic $\mathrm{Mn}-\mathrm{O}, \mathrm{Mn}-\mathrm{Mn}_{\text {edge, }}$ and $\mathrm{Mn}-\mathrm{Mn}_{\text {corner }}$ features of tunnel structured $\alpha-\mathrm{MnO}_{2}$ (Fig. 10). ${ }^{75,76}$ During the discharge (lithiation), the intensity of peaks significantly decreased suggesting a structural distortion caused by the JahnTeller distortion of the reduced manganese species. ${ }^{17,43,75}$

Modeling of the EXAFS data for $\mathrm{K}_{0.00} \mathrm{Mn}_{8} \mathrm{O}_{16}, \mathrm{~K}_{0.32} \mathrm{Mn}_{8} \mathrm{O}_{16}$, and $\mathrm{K}_{0.75} \mathrm{Mn}_{8} \mathrm{O}_{16}$ discharged to various Faradaic electron equivalents (e.e.) during the initial discharge elucidates the subtle, but significant, variation in crystal structure changes at various levels of lithiation. As observed in Fig. 11, a consistent trend emerges at high levels of lithiation in which with increasing $\mathrm{K}^{+}$in the tunnels, an increase in $\mathrm{Mn}-\mathrm{Mn}$ wall distortion is observed. Specifically, the $\mathrm{Mn}$ $\mathrm{Mn}_{\text {edge sharing }}$ octahedra initially have similar interatomic distances in the initial structures across all $\mathrm{K}^{+}$amounts $(2.94 \pm 0.02 \AA$ ) but at 0.5 e.e. per $\mathrm{MnO}_{2}$ formula unit expand to $3.19 \pm 0.03 \AA$ for the $\mathrm{K}_{0.75} \mathrm{Mn}_{8} \mathrm{O}_{16}, 3.10 \pm 0.04 \AA$ for the $\mathrm{K}_{0.32} \mathrm{Mn}_{8} \mathrm{O}_{16}$ and $3.02 \pm 0.04 \AA$ for the $\mathrm{K}_{0.00} \mathrm{Mn}_{8} \mathrm{O}_{16}$ samples. This clear expansion of the edge sharing $\left[\mathrm{MnO}_{6}\right]$ octahedra section of the tunnel walls has been previously predicted via density function theory (DFT) calculations. ${ }^{74}$ A similar

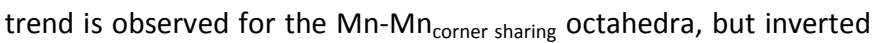
with the $\mathrm{K}_{0.75} \mathrm{Mn}_{8} \mathrm{O}_{16}$ showing a reduced interatomic distance, while the $\mathrm{K}_{0.00} \mathrm{Mn}_{8} \mathrm{O}_{16}$ structure shows minimal expansion.

It is also clear from the EXAFS analysis that much of the structural distortion is limited to the a-b plane, as the $\mathrm{Mn}-\mathrm{Mn}$ interatomic distance along the c-axis shows nearly no change between the initial undischarged crystal structure and at the discharge state of 0.5 e.e. per $\mathrm{MnO}_{2}$ unit. In addition, the DebyeWaller factor along the c-axis shows minimal increase from the undischarged state to the 0.5 e.e. discharged state $\left(0.001 \pm 0.001 \AA^{-}\right.$ 2 and $0.005 \pm 0.001 \AA^{-2}$ respectively for $\mathrm{K}_{0.00} \mathrm{Mn}_{8} \mathrm{O}_{16}$ ) compared to 
the $\mathrm{Mn}-\mathrm{Mn}_{\text {edge sharing }}\left(0.003 \pm 0.001 \AA^{-2}\right.$ and $0.013 \pm 0.002 \AA^{-2}$ respectively).

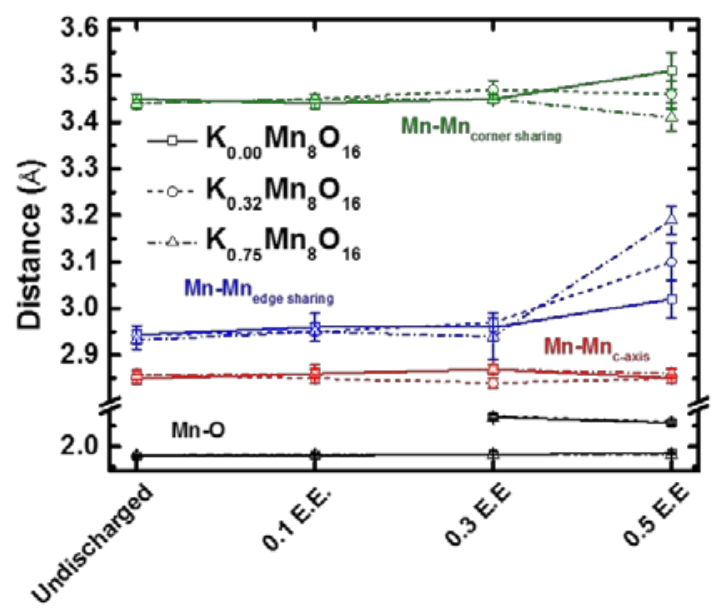

Fig. 11 EXAFS interatomic distance modeling results for $\mathrm{K}_{0.00} \mathrm{Mn}_{8} \mathrm{O}_{16}$, $\mathrm{K}_{0.32} \mathrm{Mn}_{8} \mathrm{O}_{16}$, and $\mathrm{K}_{0.75} \mathrm{Mn}_{8} \mathrm{O}_{16}$ at $\mathrm{O}$ (undischarged), $0.1,0.3$, and 0.5 lithiation levels (electron equivalents (e.e.) per $\mathrm{MnO}_{2}$ formula unit. Distinct $\mathrm{Mn}-\mathrm{O}$ (black), $\mathrm{Mn}-\mathrm{Mn}_{\mathrm{c}-\mathrm{axis}}$ (red), $\mathrm{Mn}-\mathrm{Mn}_{\text {edge }}$ sharing (blue) and $\mathrm{Mn}-\mathrm{Mn}_{\text {corner sharing }}$ (green) are displayed.

In addition to the $\mathrm{Mn}-\mathrm{Mn}$ interatomic distance variations, a shift in $\mathrm{Mn}-\mathrm{O}$ coordination is observed beyond 0.3 e.e. for all samples measured. A distinct $\mathrm{Mn}-\mathrm{O}$ distance is detected at ca. $2.35 \pm 0.03 \AA$, significantly expanded from the majority of the $\mathrm{Mn}-\mathrm{O}$ coordination of ca. $1.90 \pm 0.01 \AA$ with ca. 1 neighboring oxygen atom. This suggests at higher levels of lithiation, a distortion of some of the $\mathrm{Mn}$ octahedra occurs, likely occurring within the $a$-b lattice plane where the majority of the Mn-Mn distortion is observed.

EXAFS spectra were also collected on electrodes on the $50^{\text {th }}$ cycle discharge and charge state. The R-space of each is presented in the Fig. S13, where a clear shift in the local environment of the $\mathrm{K}_{0.75} \mathrm{Mn}_{8} \mathrm{O}_{16}$ sample is observed suggesting a slightly different local structure.

\section{Discussion}

Physicochemical properties and chemical composition can play a significant role in the electrochemistry of $\mathrm{K}_{\mathrm{x}} \mathrm{Mn}_{8} \mathrm{O}_{16}$ materials. Since the $\mathrm{K}^{+}$content was the only variable in the $\mathrm{K}_{\mathrm{x}} \mathrm{Mn}_{8} \mathrm{O}_{16}$ materials studied herein, we were able to independently study the role of $\mathrm{K}^{+}$ on the electrochemistry of $\mathrm{K}_{\mathrm{x}} \mathrm{Mn}_{8} \mathrm{O}_{16}$ cathodes in rechargeable lithium based batteries. In general, lower $\mathrm{K}^{+}$containing samples $\left(\mathrm{K}_{0.00} \mathrm{Mn}_{8} \mathrm{O}_{16}\right.$ and $\left.\mathrm{K}_{0.32} \mathrm{Mn}_{8} \mathrm{O}_{16}\right)$ demonstrated higher delivered capacity, improved capacity retention, higher effective $\mathrm{Li}^{+}$ion diffusion coefficients, and higher discharge voltage plateaus than higher $\mathrm{K}^{+}$containing $\mathrm{K}_{\mathrm{x}} \mathrm{Mn}_{8} \mathrm{O}_{16}$ samples $\left(\mathrm{K}_{0.51} \mathrm{Mn}_{8} \mathrm{O}_{16}, \mathrm{~K}_{0.70} \mathrm{Mn}_{8} \mathrm{O}_{16}\right.$ and $\left.\mathrm{K}_{0.75} \mathrm{Mn}_{8} \mathrm{O}_{16}\right)$.

The $\mathrm{K}^{+}$free $\mathrm{K}_{0.00} \mathrm{Mn}_{8} \mathrm{O}_{16}$ sample delivered a discharge capacity of $123 \mathrm{mAh} / \mathrm{g}$ at the end of 100 cycles, which is almost 2 times higher than the capacity of high potassium containing $\mathrm{K}_{0.75} \mathrm{Mn}_{8} \mathrm{O}_{16}(68$
$\mathrm{mAh} / \mathrm{g}$ ). The discharge curve of $\mathrm{K}_{0.00} \mathrm{Mn}_{8} \mathrm{O}_{16}$ has two plateaus (2.8 and $2.66 \mathrm{~V}$ ), where $\mathrm{K}^{+}$containing $\mathrm{K}_{\mathrm{x}} \mathrm{Mn}_{8} \mathrm{O}_{16}$ samples have only one slopped discharge plateau (Fig. 7). The observation of two discharge

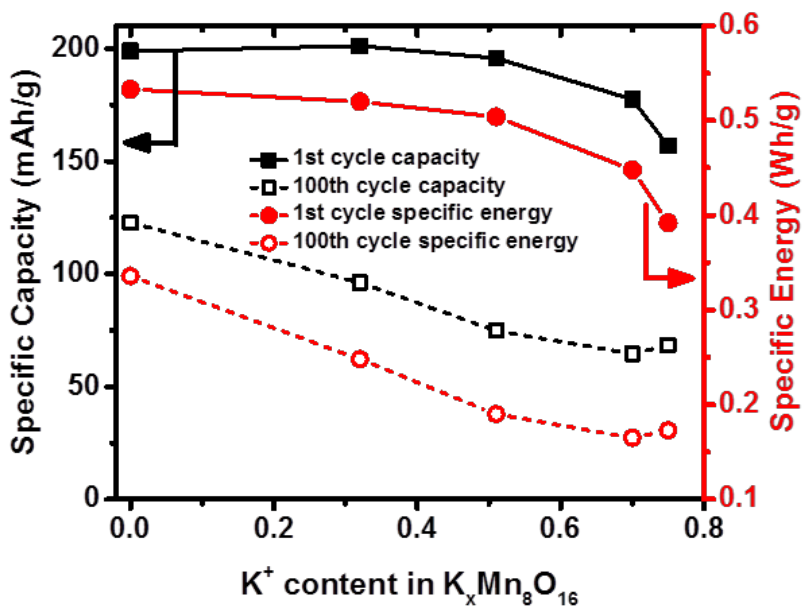

Fig. 12. Evolution of specific capacity and energy at 1st and 100th cycle with $\mathrm{K}^{+}$content of $\mathrm{K}_{\mathrm{x}} \mathrm{Mn}_{8} \mathrm{O}_{16}$ samples, where $\mathrm{X}=0.00,0.32$, $0.51,0.70$, and 0.75 .

plateaus is consistent with two observed reduction peaks in the cyclic voltammogram (Fig. 6a). The first plateau disappears in the second cycle (consistent with the $\mathrm{CV}$ ) adopting a single slopped plateau consistent with prior reports. ${ }^{13,29,48}$ The discharge voltage plateau is the highest for $\mathrm{K}_{0.00} \mathrm{Mn}_{8} \mathrm{O}_{16}(2.8 \mathrm{~V})$ and gradually decreases with increasing $\mathrm{K}^{+}$content (Fig. $7 \mathrm{~b}$ ). The results are also consistent with the cathodic peak positions of the cyclic voltammograms, where the order for $\mathrm{Ep}$ is $\mathrm{K}_{0.00} \mathrm{Mn}_{8} \mathrm{O}_{16}>$ $\mathrm{K}_{0.32} \mathrm{Mn}_{8} \mathrm{O}_{16}>\mathrm{K}_{0.51} \mathrm{Mn}_{8} \mathrm{O}_{16}>\mathrm{K}_{0.70} \mathrm{Mn}_{8} \mathrm{O}_{16}>\mathrm{K}_{0.75} \mathrm{Mn}_{8} \mathrm{O}_{16}$ (Table 4). The reduction peaks of the $\mathrm{CV}$ are more intense and narrower with smaller cathodic and anodic peak separation for lower $\mathrm{K}^{+}$ $\left(\mathrm{K}_{0.00} \mathrm{Mn}_{8} \mathrm{O}_{16}\right.$ and $\left.\mathrm{K}_{0.32} \mathrm{Mn}_{8} \mathrm{O}_{16}\right)$ containing samples indicating improved electrochemical reversibility (Fig. 6). ${ }^{9} \quad \mathrm{~K}_{0.00} \mathrm{Mn}_{8} \mathrm{O}_{16}$ delivered the highest capacity and energy throughout the galvanostatic cycling test, Fig. 12 . The $\mathrm{CV}$ peak separation $\left(\Delta \mathrm{E}_{\mathrm{p}}\right)$ of $\mathrm{K}_{0.00} \mathrm{Mn}_{8} \mathrm{O}_{16}$ is $0.28 \mathrm{~V}$ in the $1^{\text {st }}$ cycle, which is apparently smaller than $0.58 \mathrm{~V}$ of the $\mathrm{K}^{+}$ion containing $\mathrm{K}_{\mathrm{x}} \mathrm{Mn}_{8} \mathrm{O}_{16}$. The smaller $\Delta \mathrm{E}_{\mathrm{p}}$ value of $\mathrm{K}_{0.00} \mathrm{Mn}_{8} \mathrm{O}_{16}$ indicates the $\mathrm{K}^{+}$free sample has less polarization than the $\mathrm{K}_{\mathrm{x}} \mathrm{Mn}_{8} \mathrm{O}_{16}$ samples. Moreover, the $\mathrm{AC}$ impedance data of the $\mathrm{K}_{0.00} \mathrm{Mn}_{8} \mathrm{O}_{16}$ sample shows a charge transfer resistance value of $\sim 10 \mathrm{ohm}$, which is smaller than 20-30 ohm of the $\mathrm{K}^{+}$ion containing samples $\left(\mathrm{K}_{\mathrm{x}} \mathrm{Mn}_{8} \mathrm{O}_{16}\right)$, Fig. S14. The smaller charge transfer resistance of $\mathrm{K}_{0.00} \mathrm{Mn}_{8} \mathrm{O}_{16}$ is consistent with its smaller peak separation value.

$\mathrm{Li}^{+}$ion diffusion is an important parameter impacting rate capability. ${ }^{19,64,72}$ Rate capability (Fig. 8) and GITT (Fig. 9) studies on $\mathrm{K}_{0.00} \mathrm{Mn}_{8} \mathrm{O}_{16}, \mathrm{~K}_{0.32} \mathrm{Mn}_{8} \mathrm{O}_{16}$, and $\mathrm{K}_{0.75} \mathrm{Mn}_{8} \mathrm{O}_{16}$ samples suggest a correlation between $\mathrm{K}^{+}$content and rate capability. $\mathrm{K}_{0.00} \mathrm{Mn}_{8} \mathrm{O}_{16}$ showed the highest rate capability delivering $116 \mathrm{mAh} / \mathrm{g}$ at a discharge rate of $400 \mathrm{~mA} / \mathrm{g}$. The order of delivered capacity is $\mathrm{K}_{0.00} \mathrm{Mn}_{8} \mathrm{O}_{16}>\mathrm{K}_{0.32} \mathrm{Mn}_{8} \mathrm{O}_{16}>\mathrm{K}_{0.75} \mathrm{Mn}_{8} \mathrm{O}_{16}$. Similarly, low $\mathrm{K}^{+}$containing $\mathrm{K}_{0.00} \mathrm{Mn}_{8} \mathrm{O}_{16}$ and $\mathrm{K}_{0.32} \mathrm{Mn}_{8} \mathrm{O}_{16}$ had higher lithium ion diffusion coefficients $\left(D_{\mathrm{Li}+}\right)$ at lithiation levels $>0.25$ per $\mathrm{MnO}_{2}$. Intuitively, the $\mathrm{K}^{+}$within the tunnel may impede $\mathrm{Li}^{+}$diffusion causing poor rate capability and low $D_{\text {Li+ }}$ values. ${ }^{29,} 62,63$ However, discussions on the 
effect of tunnel cations on $\mathrm{Li}^{+}$ion diffusion in $\mathrm{K}_{\mathrm{x}} \mathrm{Mn}_{8} \mathrm{O}_{16}$ materials are not consistent. ${ }^{16,29,48,62-64,77}$ This is reasonable since the diffusion of the lithium ion does not solely depend on the cation occupancy in the $2 \times 2$ tunnels but also on surface defects, dopants, and diffusion length (particle size). ${ }^{20,47,64}$ For example, ionic diffusion time can be reduced by two orders of magnitude when the diffusion length is decreased from $100 \mathrm{~nm}$ to $10 \mathrm{~nm} .{ }^{64}$ In this work, the role of the tunnel metal cation in the electrochemistry was more directly apparent as the $\mathrm{K}_{\mathrm{x}} \mathrm{Mn}_{8} \mathrm{O}_{16}$ samples were synthesized with the same procedure and have similar morphology (particle size), surface area, chemical composition, and crystallite size. The samples with higher $\mathrm{K}^{+}$amounts in the initial structure yielded lower specific capacity and reduced capacity retention. The larger structural distortions observed in those samples through EXAFS modeling indicated reduced structural stability of those samples negatively impacting the electrochemistry.

Our findings may initially appear surprising in light of a recent publication concerning the impact of $\mathrm{K}^{+}$on the electrochemical properties of $\alpha-\mathrm{MnO}_{2}$ in lithium based batteries, which concluded that the presence of higher $\mathrm{K}^{+}$can have a strong beneficial effect with respect to increased electronic conductivity and $\mathrm{Li}^{+}$diffusivity, resulting in enhanced rate capability. ${ }^{31}$ However, further exploration of the physicochemical properties of the materials used in the prior study and this study can help rationalize both sets of results. In the prior report, 2- and 4-day $60^{\circ} \mathrm{C}$ nitric acid treatments were used to decrease the $\mathrm{K}^{+}$content of the parent sample, with compositions of $\mathrm{K}_{0.154} \mathrm{MnO}_{2}$ for the parent material (corresponding to $\left.\mathrm{K}_{1.23} \mathrm{Mn}_{8} \mathrm{O}_{16}\right), \mathrm{K}_{0.085} \mathrm{MnO}_{2}$ for the 2-day acid treated sample (corresponding to $\mathrm{K}_{0.68} \mathrm{Mn}_{8} \mathrm{O}_{16}$ ) and $\mathrm{K}_{0.026} \mathrm{MnO}_{2}$ for the 4-day acid treated sample (corresponding to $\mathrm{K}_{0.208} \mathrm{Mn}_{8} \mathrm{O}_{16}$ ), where the compositions were determined by Rietveld refinement. ${ }^{31}$ Concomitant with lowering the $\mathrm{K}^{+}$amount, the acid treatment increased the average oxidation state of manganese (AOS, 3.46 to 3.85 for the $\mathrm{K}_{0.154} \mathrm{MnO}_{2}$ parent material and the $\mathrm{K}_{0.026} \mathrm{MnO}_{2}$ product of 4-day acid treatment, respectively). ${ }^{31}$ In order to deconvolute the effects of $\mathrm{K}^{+}$content and AOS of manganese on the electrochemistry of $\alpha-\mathrm{MnO}_{2}\left(\mathrm{Mn}_{8} \mathrm{O}_{16}\right)$ structured materials, we subjected metal cation free $\mathrm{K}_{0.00} \mathrm{Mn}_{8} \mathrm{O}_{16}$ to a similar acid treatment (specifically, treatment in $\mathrm{HNO}_{3}$ at $60^{\circ} \mathrm{C}$ for $72 \mathrm{~h}$ ). The resulting acid treated $\mathrm{K}_{0.00} \mathrm{Mn}_{8} \mathrm{O}_{16}$ had showed a consistent $\mathrm{x}$-ray diffraction pattern with an elevated average manganese oxidation state (Fig. S15 and S16). As determined by XPS, the AOS of manganese increased from 3.64 to 3.82 after acid treatment for our samples, consistent with AOS change as a function of acid treatment time described in the prior report. ${ }^{31}$ Electrochemical cells were assembled using the parent and acid treated $\mathrm{K}_{0.00} \mathrm{Mn}_{8} \mathrm{O}_{16}$, where the OCV increased by $0.42 \mathrm{~V}$ after acid treatment (3.12 vs. $3.54 \mathrm{~V}$ ), consistent with the higher manganese AOS (Fig. S16). Notably, while the acid treated $\mathrm{K}_{0.00} \mathrm{Mn}_{8} \mathrm{O}_{16}$ showed a higher voltage plateau than the parent $\mathrm{K}_{0.00} \mathrm{Mn}_{8} \mathrm{O}_{16}(2.87$ vs. $2.80 \mathrm{~V})$, both cycle stability and rate capability decreased, indicating a negative effect of acid treatment (Fig.13a and b). The capacity retention after 100 cycles was $62 \%$ for the parent $\mathrm{K}_{0.00} \mathrm{Mn}_{8} \mathrm{O}_{16}$ but $46 \%$ for the acid treated $\mathrm{K}_{0.00} \mathrm{Mn}_{8} \mathrm{O}_{16}$. In the rate capability test, the parent $\mathrm{K}_{0.00} \mathrm{Mn}_{8} \mathrm{O}_{16}$ showed higher capacity relative to the acid treated $\mathrm{K}_{0.00} \mathrm{Mn}_{8} \mathrm{O}_{16}$ at all rates. At the highest charge-discharge rate of $400 \mathrm{~mA} / \mathrm{g}$, the parent $\mathrm{K}_{0.00} \mathrm{Mn}_{8} \mathrm{O}_{16}$ delivered $46 \%$ higher capacity than the acid treated sample (115 vs. $78 \mathrm{mAh} / \mathrm{g}$ ), Fig. 13c. These results show
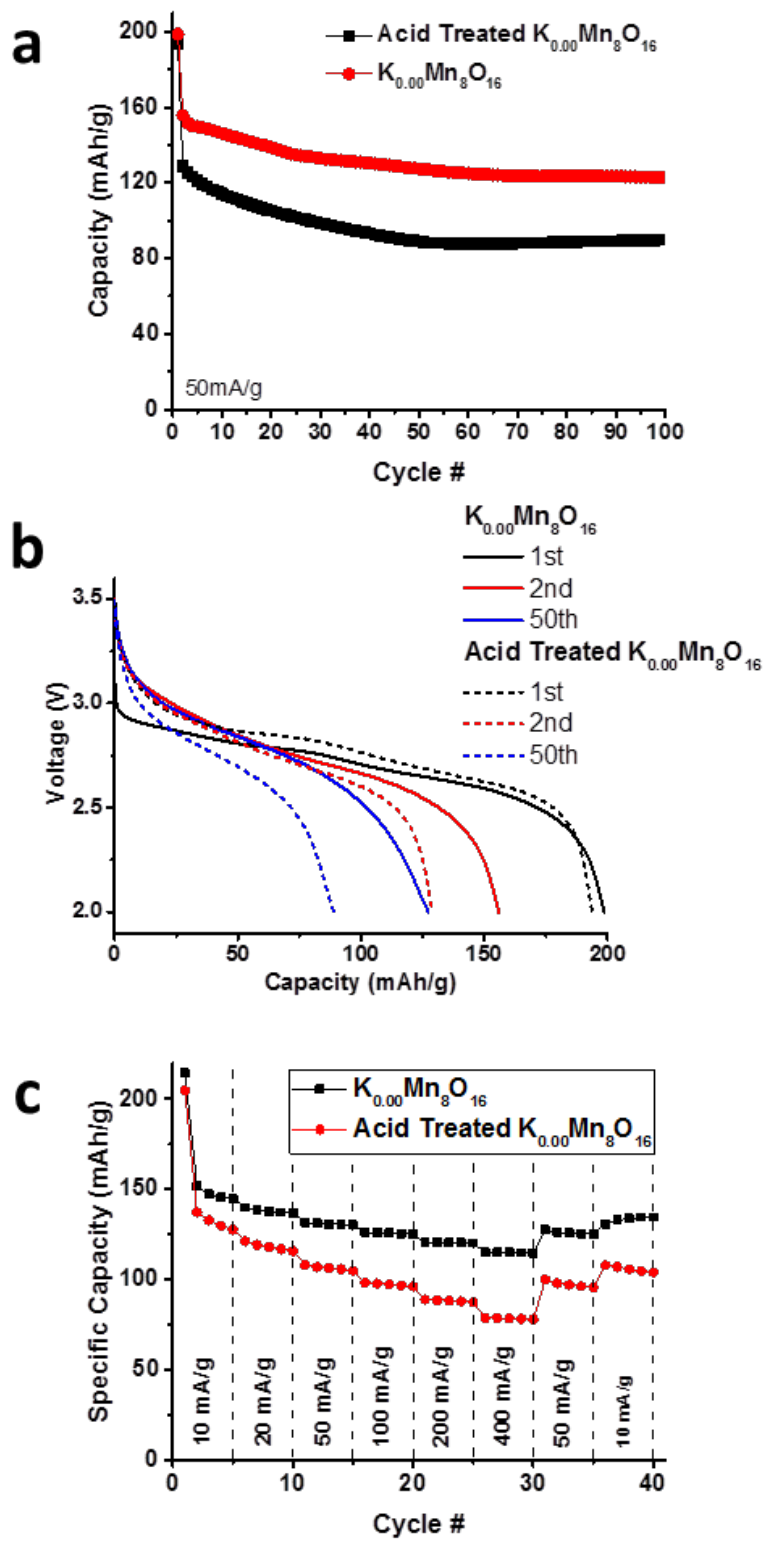

that independent of $\mathrm{K}^{+}$content, acid treatment can significantly influence the electrochemistry of $\alpha-\mathrm{MnO}_{2}$ tunnel structured materials.

Fig. 13 Electrochemistry of tunnel metal cation free $\mathrm{K}_{0.00} \mathrm{Mn}_{8} \mathrm{O}_{16}$ and Acid Treated $\mathrm{K}_{0.00} \mathrm{Mn}_{8} \mathrm{O}_{16}$ : (a) Evolution of discharge capacity (mAh/g) over 100 cycles, (b) Representative discharge profiles at cycles $1,2,10$, and 50 . The cells were discharged-charged at a rate of $50 \mathrm{~mA} / \mathrm{g}$. (c) Rate capability at various current densities (in the order of $10,20,50,100,200,400,50$, and $10 \mathrm{~mA} / \mathrm{g}$ ).

\section{Conclusions}


Cryptomelane type tunnel structured manganese dioxides $\left(\mathrm{K}_{\mathrm{x}} \mathrm{Mn}_{8} \mathrm{O}_{16}\right)$ with different $\mathrm{K}^{+}$amounts were prepared by a hydrothermal redox reaction. $\mathrm{K}^{+}$content of $\mathrm{K}_{\mathrm{x}} \mathrm{Mn}_{8} \mathrm{O}_{16}$ was controlled by altering reactant ratio of $\mathrm{K}_{2} \mathrm{SO}_{4} /\left(\mathrm{NH}_{4}\right)_{2} \mathrm{SO}_{4}$. The $\mathrm{K}^{+}$ amount in the $\mathrm{K}_{\mathrm{x}} \mathrm{Mn}_{8} \mathrm{O}_{16}$ materials ranges between 0 and 0.75 per structural unit formula of $\mathrm{K}_{\mathrm{x}} \mathrm{Mn}_{8} \mathrm{O}_{16}$, where $0 \leq \mathrm{x} \leq 0.75$. The nanofibrous $\mathrm{K}_{\mathrm{x}} \mathrm{Mn}_{8} \mathrm{O}_{16}$ materials had similar morphology, crystallite size, surface area, tunnel water content, average manganese oxidation state, and surface chemical composition (surface defects). This set of samples allowed us to investigate the role of $\mathrm{K}^{+}$in the electrochemistry of $\mathrm{K}_{x} \mathrm{Mn}_{8} \mathrm{O}_{16}$ cathodes in rechargeable lithium batteries by minimizing the effects of the other parameters.

The electrochemistry of $\mathrm{K}_{\mathrm{x}} \mathrm{Mn}_{8} \mathrm{O}_{16}$ materials with different $\mathrm{K}^{+}$ amounts was evaluated using cyclic voltammetry, galvanostatic cycling, rate capability, and GITT tests. The results suggested that $\mathrm{K}_{\mathrm{x}} \mathrm{Mn}_{8} \mathrm{O}_{16}$ materials with lower $\mathrm{K}^{+}(\mathrm{x}=0.0,0.32)$ content show higher delivered capacity and improved capacity retention, higher discharge voltage, and higher lithium ion diffusion coefficients $\left(D_{\mathrm{Li}+}\right)$ than high $\mathrm{K}^{+}(\mathrm{x}=0.51,0.70,0.75)$ containing $\mathrm{K}_{\mathrm{x}} \mathrm{Mn}_{8} \mathrm{O}_{16}$ materials. In a galvanostatic cycling test, potassium free $\mathrm{K}_{0.00} \mathrm{Mn}_{8} \mathrm{O}_{16}$ delivered a discharge capacity of $123 \mathrm{mAh} / \mathrm{g}$ at the $100^{\text {th }}$ cycle (82\% capacity retention compared to $2^{\text {nd }}$ cycle and $62 \%$ compared to the first cycle) and specific energy of $533 \mathrm{Wh} / \mathrm{kg}$ in the first cycle. The analogous high $\mathrm{K}^{+}$containing $\mathrm{K}_{0.75} \mathrm{Mn}_{8} \mathrm{O}_{16}$ delivered $65 \mathrm{mAh} / \mathrm{g}$ capacity with a capacity retention of $36 \%$. While at low lithiation amounts $\left(<0.25\right.$ electron equivalents per $\left.\mathrm{MnO}_{2}\right)$, the $\mathrm{K}_{\mathrm{x}} \mathrm{Mn}_{8} \mathrm{O}_{16}$ materials showed similar $\mathrm{D}_{\mathrm{Li}}$ values, at high lithiation levels $(0.25$ to 0.8 electron equivalents), the $\mathrm{K}^{+}$free $\mathrm{K}_{0.00} \mathrm{Mn}_{8} \mathrm{O}_{16}$ had higher $\mathrm{D}_{\text {Li+ }}$ values compared to high $\mathrm{K}^{+}$containing $\mathrm{K}_{0.75} \mathrm{Mn}_{8} \mathrm{O}_{16}$. Thus, our results indicate that the presence of $\mathrm{K}^{+}$in the tunnels impedes the $\mathrm{Li}^{+}$diffusion, where the samples with lower $\mathrm{K}^{+}$amounts in the initial structure yielded higher specific capacity and improved capacity retention. The smaller structural distortions upon lithiation observed in the low $\mathrm{K}^{+}$content samples through EXAFS modelling indicated improved structural stability which positively impacted their electrochemistry.

\section{Conflicts of Interest}

There are no conflicts of interest to declare.

\section{Acknowledgements}

This work was supported as part of the Center for Mesoscale Transport Properties, an Energy Frontier Research Center supported by the U.S. Department of Energy, Office of Science, Basic Energy Sciences, under award \#DE-SC0012673. Use of the National Synchrotron Light Source II, (XPD) Brookhaven National Laboratory, was supported by the U.S. Department of Energy, Office of Science, Office of Basic Energy Sciences, under Contract No. DESC0012704. The XPS experiments were carried out at the Center for Functional Nanomaterials at Brookhaven National Laboratory, which is supported by the Department of Energy, Office of Basic Energy Sciences (DE-AC02-98CH10886). TEM work was supported by the U.S. Department of Energy, Office of Basic Energy Science,
Division of Materials Science and Engineering, under Contract No. DE-SC0012704.

\section{References}

1. A. S. Poyraz, W. Song, D. Kriz, C.-H. Kuo, M. S. Seraji and S. L. Suib, ACS Applied Materials \& Interfaces, 2014, 6, 10986-10991.

2. S. L. Suib, Journal of Materials Chemistry, 2008, 18, 16231631.

3. J. Yuan, X. Liu, O. Akbulut, J. Hu, S. L. Suib, J. Kong and F. Stellacci, Nature Nanotechnology, 2008, 3, 332-336.

4. T. Zhang, X. Zhang, J. Ng, H. Yang, J. Liu and D. D. Sun, Chemical Communications, 2011, 47, 1890-1892.

5. C.-H. Chen and S. L. Suib, Journal of the Chinese Chemical Society, 2012, 59, 465-472.

6. S. L. Suib, Accounts Chem. Res., 2008, 41, 479-487.

7. A. Iyer, J. Del-Pilar, C. K. King'ondu, E. Kissel, H. F. Garces, H. Huang, A. M. El-Sawy, P. K. Dutta and S. L. Suib, The Journal of Physical Chemistry C, 2012, 116, 6474-6483.

8. M. Özacar, A. S. Poyraz, H. C. Genuino, C.-H. Kuo, Y. Meng and S. L. Suib, Applied Catalysis A: General, 2013, 462463, 64-74.

9. K. J. Takeuchi, S. Z. Yau, M. C. Menard, A. C. Marschilok and E. S. Takeuchi, ACS Appl Mater Interfaces, 2012, 4, 5547-5554.

10. H. Pan, Y. Shao, P. Yan, Y. Cheng, K. S. Han, Z. Nie, C. Wang, J. Yang, X. Li, P. Bhattacharya, K. T. Mueller and J. Liu, Nature Energy, 2016, 1, 16039.

11. J. Huang, A. S. Poyraz, K. J. Takeuchi, E. S. Takeuchi and A. C. Marschilok, Chemical Communications, 2016, 52, 40884091.

12. J. Liu, V. Makwana, J. Cai, S. L. Suib and M. Aindow, The Journal of Physical Chemistry B, 2003, 107, 9185-9194.

13. C. S. Johnson and M. M. Thackeray, J. Power Sources, 2001, 97-8, 437-442.

14. C. S. Johnson, J. Power Sources, 2007, 165, 559-565.

15. B. W. Byles, N. K. R. Palapati, A. Subramanian and E. Pomerantseva, APL Mater., 2016, 4, 11.

16. C. Zhang, C. Feng, P. Zhang, Z. Guo, Z. Chen, S. Li and H. Liu, RSC Adv., 2012, 2, 1643-1649.

17. Y. Yuan, A. Nie, G. M. Odegard, R. Xu, D. Zhou, S. Santhanagopalan, K. He, H. Asayesh-Ardakani, D. D. Meng, R. F. Klie, C. Johnson, J. Lu and R. ShahbazianYassar, Nano Letters, 2015, 15, 2998-3007.

18. D. Su, H.-J. Ahn and G. Wang, Journal of Materials Chemistry A, 2013, 1, 4845.

19. R. R, S. T. S, R. S, L. V, S. Kalluri, T. N. Kim, S. V. Nair and A. Balakrishnan, Materials Research Bulletin, 2015, 70, 1-6.

20. N. Kumagai, T. Sasaki, S. Oshitari and S. Komaba, J. New Mat. Electrochem. Syst., 2006, 9, 175-180.

21. T. Ohzuku, M. Kitagawa, K. Sawai and T. Hirai, Journal of The Electrochemical Society, 1991, 138, 360-365.

22. H. Zheng, C. Feng, S.-J. Kim, S. Yin, H. Wu, S. Wang and S. Li, Electrochimica Acta, 2013, 88, 225-230.

23. N. Jabeen, Q. Xia, S. V. Savilov, S. M. Aldoshin, Y. Yu and H. Xia, ACS Applied Materials \& Interfaces, 2016, 8, 3373233740.

24. G. Qiu, H. Huang, S. Dharmarathna, E. Benbow, L. Stafford and S. L. Suib, Chemistry of Materials, 2011, 23, 38923901. 
25. Y.-s. Ding, X.-f. Shen, S. Sithambaram, S. Gomez, R. Kumar, V. M. B. Crisostomo, S. L. Suib and M. Aindow, Chemistry of Materials, 2005, 17, 5382-5389.

26. C. K. King'ondu, N. Opembe, C.-h. Chen, K. Ngala, H. Huang, A. Iyer, H. F. Garcés and S. L. Suib, Advanced Functional Materials, 2011, 21, 312-323.

27. J. Yuan, W.-N. Li, S. Gomez and S. L. Suib, Journal of the American Chemical Society, 2005, 127, 14184-14185.

28. N. Kijima, H. Yasuda, T. Sato and Y. Yoshimura, Journal of Solid State Chemistry, 2001, 159, 94-102.

29 C. S. Johnson, D. W. Dees, M. F. Mansuetto, M. M. Thackeray, D. R. Vissers, D. Argyriou, C. K. Loong and L. Christensen, J. Power Sources, 1997, 68, 570-577.

30. J. Hou, L. Liu, Y. Li, M. Mao, H. Lv and X. Zhao, Environmental Science \& Technology, 2013, 47, 1373013736.

31. Y. Yuan, C. Zhan, K. He, H. Chen, W. Yao, S. Sharifi-Asl, B. Song, Z. Yang, A. Nie, X. Luo, H. Wang, S. M. Wood, K. Amine, M. S. Islam, J. Lu and R. Shahbazian-Yassar, Nature Communications, 2016, 7, 13374.

32. A. P. Hammersley, S. O. Svensson, M. Hanfland, A. N. Fitch and D. Hausermann, High Pressure Research, 1996, 14, 235-248.

33. B. H. Toby and R. B. Von Dreele, Journal of Applied Crystallography, 2013, 46, 544-549. M. J. Newville, J. Synchrotron Radiat., 2001, 8, 322-324. B. Ravel and M. J. Newville, J. Synchrotron Radiat., 2005 12, 537-541.

36. F. M. Chang and M. Jansen, Angewandte Chemie International Edition, 1984, 96, 902-903.

37. J. J. Rehr and R. C. Albers, Reviews of Modern Physics, 2000, 72, 621-654.

38. J. J. Rehr, J. Mustre de Leon, S. I. Zabinsky and R. C. Albers, J. Am. Chem. Soc., 1991, 113, 5135-5140.

39. S. Cheng, L. Yang, D. Chen, X. Ji, Z.-j. Jiang, D. Ding and M. Liu, Nano Energy, 2014, 9, 161-167.

40. T. Gao, M. Glerup, F. Krumeich, R. Nesper, H. Fjellvåg and P. Norby, The Journal of Physical Chemistry C, 2008, 112, 13134-13140.

41. C. V. Ramana, M. Massot and C. M. Julien, Surface and Interface Analysis, 2005, 37, 412-416.

42. H. M. Galindo, Y. Carvajal, E. Njagi, R. A. Ristau and S. L. Suib, Langmuir : The ACS journal of surfaces and colloids, 2010, 26, 13677-13683.

43. A. S. Poyraz, J. Huang, S. Cheng, D. C. Bock, L. Wu, Y. Zhu, A. C. Marschilok, K. J. Takeuchi and E. S. Takeuchi, Green Chem., 2016, 18, 3414-3421.

44. Z. Yang, L. Trahey, Y. Ren, M. K. Y. Chan, C. Lin, J. Okasinski and M. M. Thackeray, J. Mater. Chem. A, 2015, 3, 73897398.

45. J. Dai, S. F. Y. Li, K. S. Siow and Z. Gao, Electrochimica Acta, 2000, 45, 2211-2217.

46. T. Gao and P. Norby, European Journal of Inorganic Chemistry, 2013, 2013, 4948-4957.

47. L. Wu, F. Xu, Y. Zhu, A. B. Brady, J. Huang, J. L. Durham, E. Dooryhee, A. C. Marschilok, E. S. Takeuchi and K. J. Takeuchi, ACS Nano, 2015, 9, 8430-8439.

48. N. Kijima, Y. Takahashi, J. Akimoto and J. Awaka, Journal of Solid State Chemistry, 2005, 178, 2741-2750.

49. W. Yan, T. Ayvazian, J. Kim, Y. Liu, K. C. Donavan, W. Xing, Y. Yang, J. C. Hemminger and R. M. Penner, ACS Nano, 2011, 5, 8275-8287.
50. M. Chigane and M. Ishikawa, Journal of the Electrochemical Society, 2000, 147, 2246-2251.

51. V. P. Santos, O. S. G. P. Soares, J. J. W. Bakker, M. F. R. Pereira, J. J. M. Órfão, J. Gascon, F. Kapteijn and J. L. Figueiredo, Journal of Catalysis, 2012, 293, 165-174.

52. M. Toupin, T. Brousse and D. Belanger, Chemistry of Materials, 2004, 16, 3184-3190.

53. T. Chen, H. Dou, X. Li, X. Tang, J. Li and J. Hao, Microporous and Mesoporous Materials, 2009, 122, 270 274.

54. A. S. Poyraz, J. Huang, L. Wu, D. C. Bock, Y. Zhu, A. C. Marschilok, K. J. Takeuchi and E. S. Takeuchi, Energy Technology, 2016, 4, 1358-1368.

55. V. R. Galakhov, M. Demeter, S. Bartkowski, M. Neumann, N. A. Ovechkina, E. Z. Kurmaev, N. I. Lobachevskaya, Y. M. Mukovskii, J. Mitchell and D. L. Ederer, Physical Review B, 2002, 65.

56. S. S. T. Bastos, J. J. M. Órfão, M. M. A. Freitas, M. F. R. Pereira and J. L. Figueiredo, Applied Catalysis B: Environmental, 2009, 93, 30-37.

57. P. Ragupathy, D. H. Park, G. Campet, H. N. Vasan, S.-J. Hwang, J.-H. Choy and N. Munichandraiah, The Journal of Physical Chemistry C, 2009, 113, 6303-6309.

58. S. H. Liang, F. T. G. Bulgan, R. L. Zong and Y. F. Zhu, J. Phys. Chem. C, 2008, 112, 5307-5315.

59. M. Sun, L. Yu, F. Ye, G. Diao, Q. Yu, Y. Zheng and J.-Y. Piquemal, Materials Letters, 2011, 65, 3184-3186.

60. F. ç. Larachi, J. Pierre, A. Adnot and A. Bernis, Applied Surface Science, 2002, 195, 236-250.

61. X. Wang and Y. Li, Chemistry - A European Journal, 2003, 9, 300-306.

62. H. M. Abuzeid, A. M. Hashem, N. Narayanan, H. Ehrenberg and C. M. Julien, Solid State Ionics, 2011, 182, 108-115.

63. A. M. Hashem, A. M. Abdel-Latif, H. M. Abuzeid, H. M. Abbas, H. Ehrenberg, R. S. Farag, A. Mauger and C. M. Julien, Journal of Alloys and Compounds, 2011, 509, 96699674.

64. K. Zhang, X. Han, Z. Hu, X. Zhang, Z. Tao and J. Chen, Chemical Society Reviews, 2015, 44, 699-728.

65. J.-H. Lee, R. Black, G. Popov, E. Pomerantseva, F. Nan, G. A. Botton and L. F. Nazar, Energy \& Environmental Science, 2012, 5, 9558.

66. V. D. Makwana, L. J. Garces, J. Liu, J. Cai, Y.-C. Son and S. L. Suib, Catalysis Today, 2003, 85, 225-233.

67. R. Kumar, S. Sithambaram and S. L. Suib, Journal of Catalysis, 2009, 262, 304-313.

68. A. V. Churikov, A. V. Ivanishchev, I. A. Ivanishcheva, V. O. Sycheva, N. R. Khasanova and E. V. Antipov, Electrochimica Acta, 2010, 55, 2939-2950.

$69 . \quad$ D. W. Dees, S. Kawauchi, D. P. Abraham and J. Prakash, J. Power Sources, 2009, 189, 263-268.

70. Y. Zhu, Y. Xu, Y. Liu, C. Luo and C. Wang, Nanoscale, 2013, 5, 780-787.

71. K. M. Shaju, G. V. Subba Rao and B. V. R. Chowdari, Electrochimica Acta, 2003, 48, 2691-2703.

72. X. H. Rui, N. Ding, J. Liu, C. Li and C. H. Chen, Electrochimica Acta, 2010, 55, 2384-2390.

73. M. Park, X. Zhang, M. Chung, G. B. Less and A. M. Sastry, J. Power Sources, 2010, 195, 7904-7929.

74. D. A. Tompsett and M. S. Islam, Chemistry of Materials, 2013, 25, 2515-2526. 
75. R. Zhang, X. Yu, K.-W. Nam, C. Ling, T. S. Arthur, W. Song,

A. M. Knapp, S. N. Ehrlich, X.-Q. Yang and M. Matsui, Electrochemistry Communications, 2012, 23, 110-113.

76. K.-W. Nam, M. G. Kim and K.-B. Kim, The Journal of Physical Chemistry C, 2007, 111, 749-758.

77. W. K. Pang, V. K. Peterson, N. Sharma, C. Zhang and Z. Guo, The Journal of Physical Chemistry C, 2014, 118, 39763983. 